\title{
Cambodia: Selected Issues
}

This Selected Issues report on Cambodia was prepared by a staff team of the International Monetary Fund as background documentation for the periodic consultation with this member country. As such, the views expressed in this document are those of the staff team and do not necessarily reflect the views of the Government of Cambodia or the Executive Board of the IMF.

\author{
Copies of this report are available to the public from \\ International Monetary Fund - Publication Services \\ 700 19th Street, N.W. • Washington, D.C. 20431 \\ Telephone: (202) 623-7430 - Telefax: (202) 623-7201 \\ Telex (RCA): 248331 IMF UR \\ E-mail: publications@imf.org \\ Internet: http://www.imf.org \\ Price: $\$ 15.00$ a copy
}

\section{International Monetary Fund Washington, D.C.}




\title{
INTERNATIONAL MONETARY FUND
}

\author{
CAMBODIA \\ Selected Issues \\ Prepared by Thomas Rumbaugh, Kotaro Ishi, Hong Liang (all APD), \\ and Atsushi Masuda (PDR) \\ Approved by the Asia and Pacific Department
}

August 31,2000

Contents

Page

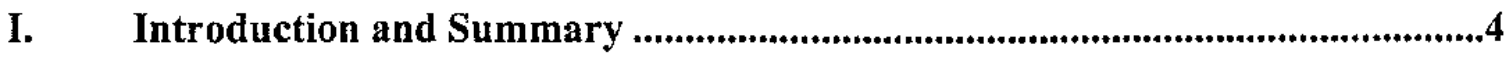

II. Sectoral Developments and Sources of Growth ...............................................5

A. Developments in Main Economic Sectors ................................................6

B. Official Aid and Foreign Direct Investment ................................................

Tables

II.1 Real GDP Growth: 1996-99........................................................................ 5

II.2 Comparative Rice Yields in Selected Asian Countries .....................................

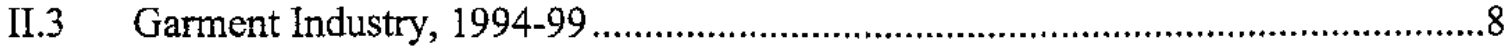

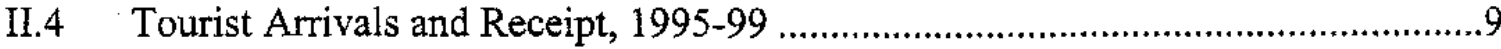

Charts

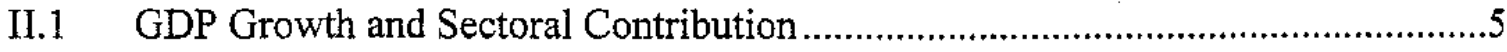

II.2 Agriculture Production in Cambodia: 1994-99 ..............................................6

Box

II.I National Accounts................................................................................ 10

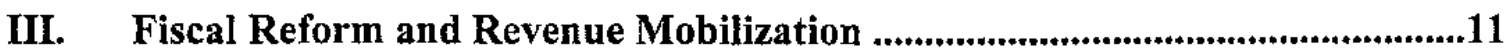

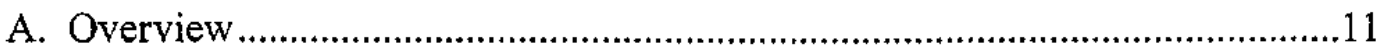

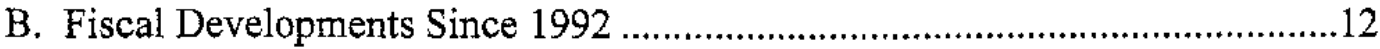

C. International Comparison of Revenue Performance ................................... 18

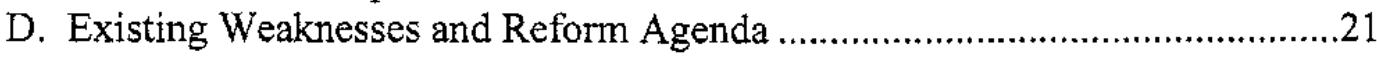

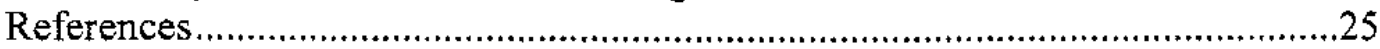

Boxes

III.I Reform in Indirect Tax System in Cambodia-Introduction of the VAT .............16

III.2 Improving Government Spending to the Priority Sectors .................................19 
III.3 Revenue Structure of Customs Duties and Law on Investment

Tables

III.1 Comparison of Tax Revenue Structure with Other Selected Countries ................26

Charts

III.1 Fiscal Development, 1990-2000 .................................................................27

III.2 Current Revenue and Domestically Financed Expenditure, 1994-2000 ...............28

III.3 Structure of Customs Duties .......................................................................29

IV. Dollarization and the Monetary Regime ........................................................30

A. History of the Monetary System .............................................................30

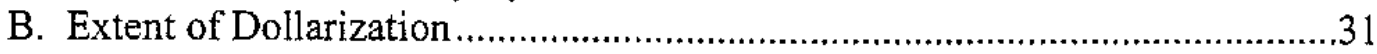

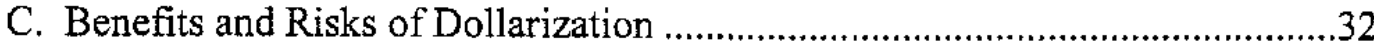

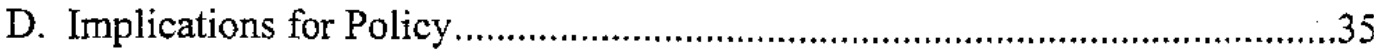

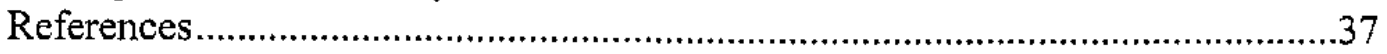

Tables

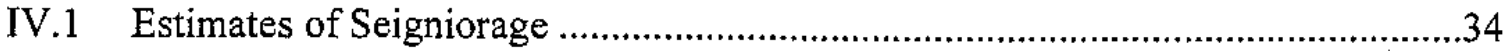

IV.2 Estimated Impact of Increase in Riel Circulation .............................................35

Charts

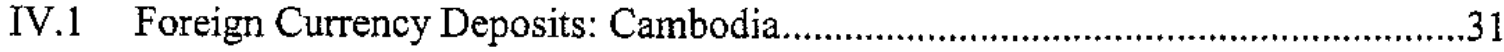

IV.2 Foreign Currency Deposits: Cambodia, Laos, and Vietnam ..............................32

V. Selected Aspects of Managing Forestry Resources.......................................38

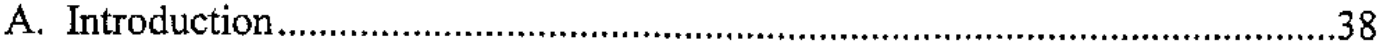

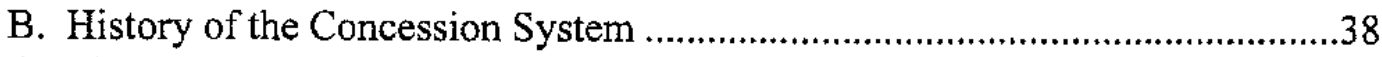

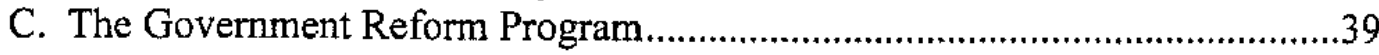

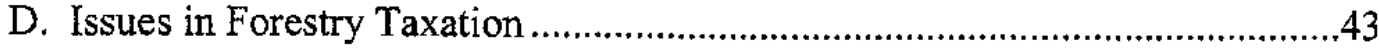

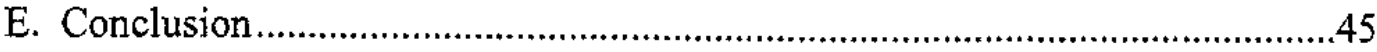

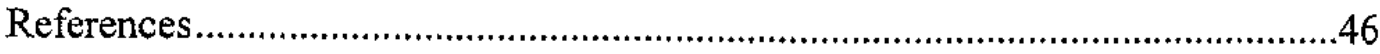

Boxes

V.1 Declaration of Measures to Ensure Forestry Management

And Eradication of Illegal Logging: 17-Point Order......................................40

V.2 Types of Forest Charges ...........................................................................47

Tables

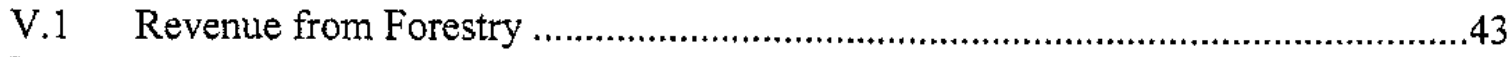

V.2 Current Status of Foreign Concessions........................................................48

Charts

V.1 Timber Prices 
VI. Export Performance and Trade Policy ............................................................50

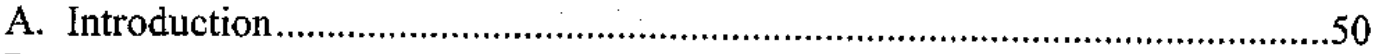

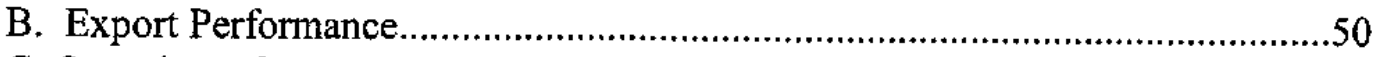

C. Overview of Current Trade Policy ...............................................................5

D. Role of Foreign Direct Investment in Export Development ...........................55

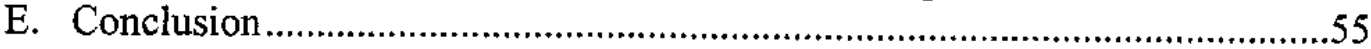

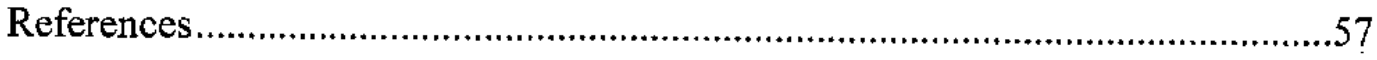

Tables

VI.1 Selected Asian Countries: Export Performance...................................................58

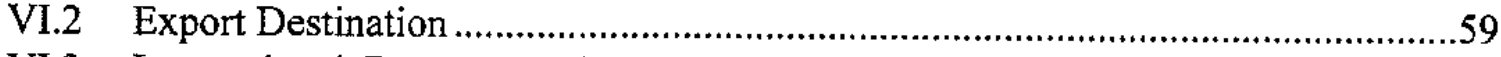

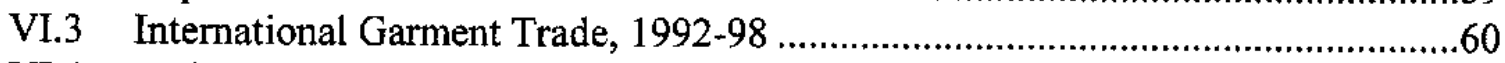

VI.4 Major Trading Partners ..........................................................................61

Chart

VI.1 Consumer Prices and Exchange Rate Developments, 1994-2000 .......................62 


\section{Introduction and Summary}

1. The Cambodian economy in the late 1960 s and early 1970 s was relatively prosperous and advanced compared to other developing countries of that time. However, a bright future was soon interupted by external and internal conflict. By the end of the $1970 \mathrm{~s}$, a substantial part of the population and all basic economic institutions had been destroyed. From the early 1980s until the signing of the Paris Peace Accord in 1991, Cambodia was predominantly a centrally planned economy. Although modest attempts at reform started in 1985, they gathered momentum after 1992 with the support of the international community, including support from the Fund, first through the Systemic Transformation Facility, and then through the Enhanced Structural Adjustment Facility (ESAF), and most recently the Poverty Reduction and Growth Facility (PRGF).

2. Significant progress has been made in establishing the foundations of a market economy, but Cambodia remains one of the poorest countries in the world with per capita income estimated at only US\$256 in 1999 . Accordingly, poverty reduction is one of the main objectives of the government's current reform program. This report briefly discusses some of the major macroeconomic issues confronting Cambodia. In this context, the following key policy issues are examined:

- Chapter II discusses the recent growth performance of the economy and presents recently updated national accounts estimates prepared by the National Institute of Statistics.

- Chapter III provides an overview of fiscal reform, the cornerstone of the authorities macroeconomic program. Revenue mobilization remains a key objective since, despite recent significant improvements, revenue performance is still low by international standards.

- Chapter IV describes the large degree of dollarization in the economy that arose from the substantial inflow of direct and indirect international assistance in the early 1990s. The costs and benefits of a high degree of dollarization are briefly discussed.

- Chapter V reports on progress in reforming the forestry sector. After a period of substantial overlogging and poor governance in the mid-1990s, the government has during the last eighteen months started to take meaningful actions. However, further significant steps and enhanced monitoring will be needed in the future to establish a sustainable system of forest management.

- Chapter VI reviews export performance and trade policy. High rates of export growth during the 1990 s were mainly due to forestry products (at an unsustainable rate) and later by a surge in garment exports. Maintaining export growth in the future will be a challenge, and will depend on maintaining Cambodia's commitment to an open trade and exchange system, and improvements in infrastructure. 


\section{SEctoral DEVELopments ANd SoURCES OF GROWTH}

1. Cambodia is one of the poorest countries in the world. The economic and social infrastructure was nearly completely destroyed during decades of war and devastation. With the departure of foreign troops in 1989, Cambodia started its long journey to national rehabilitation and reconciliation. Output production recovered strongly, and the average growth rate was about 6 percent annually in real terms in the early 1990s. Growth during this period was driven by reconstruction and a rapid expansion of private sector activity in the manufacturing and service sectors, even though agricultural output on average stagnated, partly as a result of poor rice harvests. Most economic activities, however, slumped considerably in 1997 and 1998, mainly due to the adverse impact of the July 1997 events and the regional financial crisis (Chart II.1). Overall GDP growth during these years was only sustained by an investment surge in the garment industry and an increase in illegal logging activity, while other economic sectors stagnated or declined. With the resumption of political stability, improved weather conditions, and increasing confidence, a broad-based economic expansion took place in 1999, despite a sharp contraction in logging activity. Excluding forestry, growth in real value added in the rest of the economy is estimated to have increased by 7.6 percent in 1999 (Table 1).

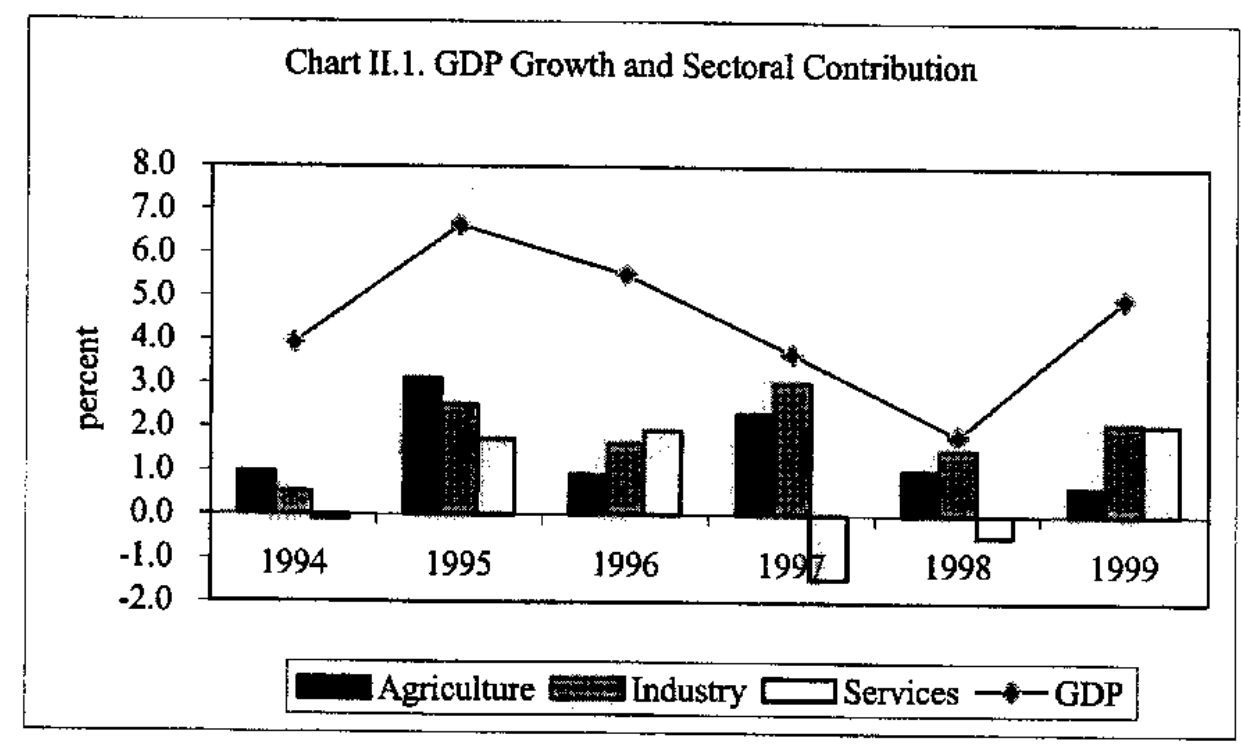

Table II.1. Real GDP Growth: 1996-99

\begin{tabular}{crrrr}
\hline & 1996 & 1997 & 1998 & 1999 \\
\hline Real GDP Growth & 5.5 & 3.7 & 1.8 & 5.0 \\
Excl. Forestry Sector & 6.7 & 1.7 & 1.9 & 7.6 \\
Excl. Forestry and Textile Sectors & 5.8 & -0.9 & -0.1 & 5.3 \\
\hline
\end{tabular}


2. This chapter reviews the growth patterns of main economic sectors in Cambodia in recent years, and tries to identify the major driving forces, as well as obstacles, to growth in the coming years. Section A focuses on the sectoral developments during this period, while Section B looks at the structure of official aid and foreign direct investment (FDI) and its impact on the economy.

\section{A. Developments in Main Economic Sectors}

3. Cambodia's economy has passed through several phases of slump and recovery in the past decade. As data for the real sector continue to be subject to a considerable degree of uncertainty, assessments of economic growth and changes in the structure of the economy must be interpreted with caution (Box 1). Nevertheless, the available data suggest that, given the low base, there is still large scope for economic reconstruction and growth in almost every sector in the economy. The realization of this potential, however, not only requires large investment in infrastructure and human capital, but also critically hinges on the maintenance of political stability.

\section{Agriculture}

4. Agriculture is the most important sector in Cambodia, accounting for about 40 percent of GDP at current prices, and employing more than 70 percent of the labor force. The preponderance of rainfed agriculture subjects the sector to high weather vulnerability, as rice accounts for nearly one third of the total agricultural value added, followed by fishery, livestock, and forestry (Chart 2). Market-oriented reforms in 1989 generated an initial expansion of agricultural output, and crop production had almost regained its 1969 level by 1991. Growth since then, however, had on average lagged behind population growth and experienced large year-to-year fluctuations, reflecting insufficient investment in the sector, over-exploitation of natural resources, and poor weather conditions.

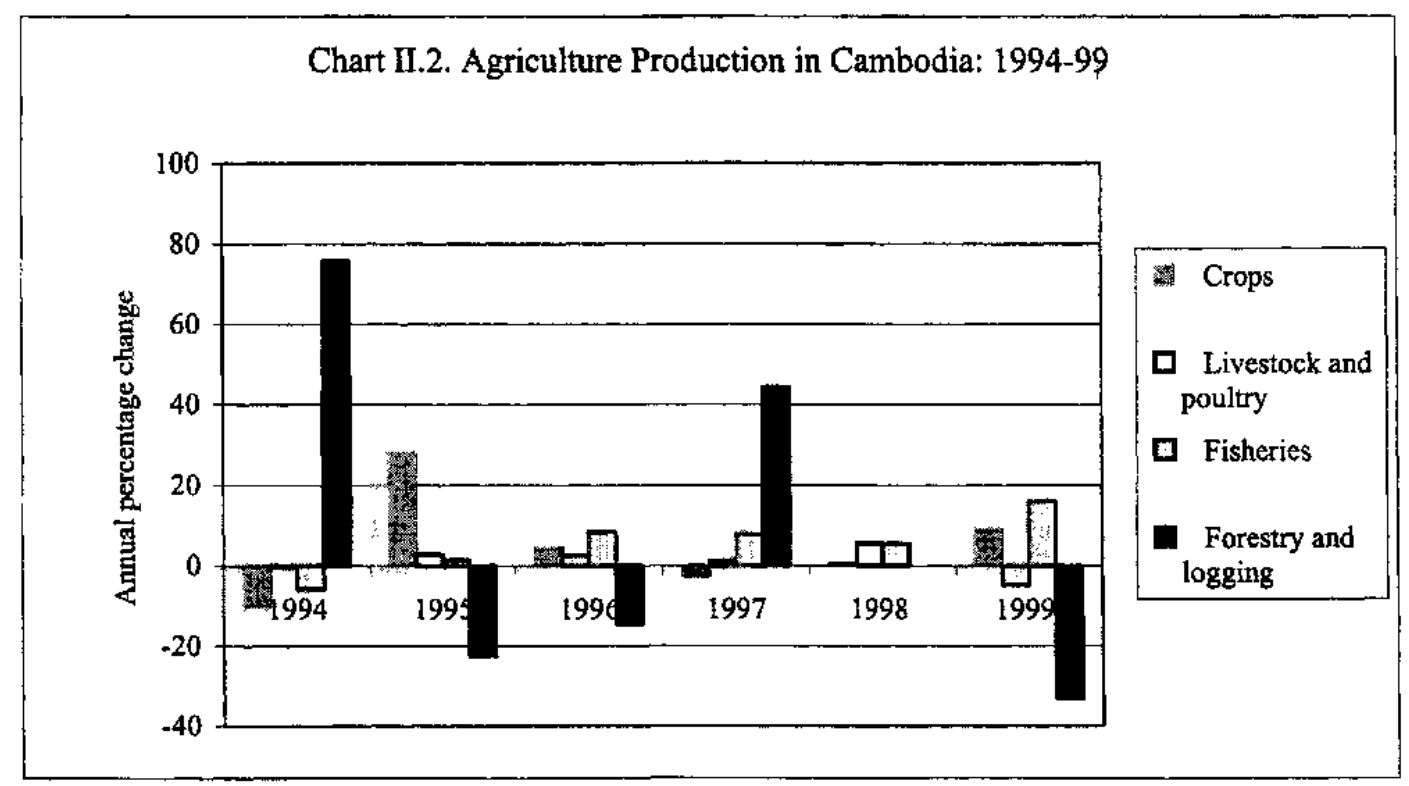


Total rice production increased in 1999 as compared with its levels in recent years, but the average yield continued to remain well below those reached by neighboring countries, partly as a result of inefficient farming techniques and very limited irrigation facilities (Table 2). On the other hand, the current low yields and potential increases in planted areas from further land mine clearing suggest significant scope exists for growth in rice production. An increase in yield to the level of Vietnam, for example, would double rice production (equivalent to 7 percent average annual growth in rice output over a ten year period). Such growth rates would lift large numbers of farm households above the poverty line, and allow for regular rice exports as in the pre-1970s.

Table II.2. Comparative Rice Yields in Selected Asian Countries (in metric tons per hectare, 1996-98)

\begin{tabular}{ll}
\hline Cambodia & 1.8 \\
China & 6.2 \\
Indonesia & 4.3 \\
Laos & 2.7 \\
Malaysia & 3.0 \\
Myanmar & 3.1 \\
Philippines & 2.9 \\
Thailand & 2.4 \\
Vietnam & 3.9 \\
Source: FAO Production Yearbook 1998 & \\
\hline
\end{tabular}

Rubber has been one of Cambodia's main cash crops. In the 1960s, Cambodia produced and exported over 50,000 metric tons of high-quality rubber yearly. The sector shrank to a fraction of its previous level during the Khmer Rouge period, and gradually recovered in the 1980 s. Rubber production, however, has stagnated in recent years, with yields and output still below their pre-1970 levels, largely reflecting the aging of rubber trees. This again suggests a potential for high growth in the future through replacement of older trees and more intensive use of fertilizers. The required major capital investment may best be achieved through privatization of the seven largest rubber plantations that still remain in the hands of the state. With a view to privatize at least one plantation by December 2001, the government corporatized all seven state-owned plantations in March 1999.

Livestock and poultry production is mostly carried out in small-scale family farming units and accounts for about 7 percent of GDP. It has recorded an average 1 percent growth rate in the last 5 years while also experiencing large year-to-year fluctuations. The fisheries sector derives most of its output from the Tonle Sap lake, one of the richest fresh-water fisheries in the world. While the sector reported double-digit real growth in 1999, its future growth is threatened by an increase in illegal fishing during the breeding season, which could result in rapid depletion if not addressed. 
The output of the forestry sector has been very difficult to estimate due to widespread illegal activity in the past. Developments in this sector are reviewed in detail in Chapter V.

\section{Industrial growth and the garment sector}

5. Fueled by a rapid increase in the number of private enterprises, industrial activity has been buoyant since the early 1990s. Starting from a very low base, output growth averaged 13 percent per year during 1993-99, driven by increased manufacturing activity and a surge in foreign direct investment in the sector. Industrial output now accounts for nearly 20 percent of GDP, up from 12 percent in 1993.

6. The garment industry, with most of its output exported, was established in Cambodia in 1993, and it has seen especially rapid growth in recent years (Table 3). From1997, most exports were destined for the US market, with the rest going to Europe. Relatively low labor costs, the availability of unfulfilled quota to the European Union, the Most Favored Nation status in Europe, and the General System of Preferences status granted by the United States in 1997 were the main driving forces behind the sector's rapid development. The pace of expansion, however, led the United States to impose quotas on 12 garment products in January 1999. Despite the restrictions, total textile exports in 1999 went up to US\$536 million.

Table II.3. Cambodia Garment Industry, 1994-99

\begin{tabular}{rrrr}
\hline & Number of factories & Number of employees & Total exports (\$ mn) \\
\hline 1994 & 7 & 8,024 & 3.4 \\
1995 & 20 & 18,703 & 26.5 \\
1996 & 24 & 24,015 & 102 \\
1997 & 67 & 51,578 & 279 \\
1998 & 129 & 79,231 & 392 \\
1999 & 152 & 96,574 & 536 \\
\hline
\end{tabular}

Source: Ministry of Commerce

\section{Tourism}

7. The tourist industry in Cambodia is still in its infancy, but there is significant growth potential in Siem Reap (Angkor Wat Archaeological Park), Phnom Penh, and the southern coastal areas. Following the formation of the first coalition government in 1993, the number of tourists visiting Cambodia increased significantly during 1994-96, before dropping sharply in 1997-98 as a result of the internal political crisis (Table 4). Only in 1999, after the security situation improved following the formation of the second coalition government, did visitor arrivals to Cambodia start to return to its level of 1996, with international tourist arrivals by air increasing by 41 percent. A similar pattern of slump and recovery has also been observed in tourism related services. After growing at double-digit rates in 1993-96, the pace of growth in hotel and restaurant construction was seriously affected in 1997-98, as work 
temporarily stopped at almost all construction sites. Construction activities picked up markedly in 1999, registering a 22 percent growth rate.

Table II.4. Cambodia:Tourist Arrivals and Receipts, 1994-99

\begin{tabular}{lll}
\hline & Visitor Arrivals by Air & $\begin{array}{l}\text { Foreign Currency Receipts } \\
\text { (mn US\$) }\end{array}$ \\
\hline 1994 & 176,617 & $\ldots$ \\
1995 & 219,680 & 53 \\
1996 & 260,489 & 82 \\
1997 & 218,843 & 68 \\
1998 & 186,333 & 45 \\
1999 & 262,907 & 63 \\
\hline
\end{tabular}

Source: Cambodia: Ministry of Tourism, and staff estimates

\section{B. Official Aid and Foreign Direct Investment (FDI)}

8. Official aid and FDI have played a key role in the reconstruction of the Cambodian economy, as most of the capital investment has come from abroad. According to the Cambodian Rehabilitation and Development Board (CRDB), which oversees the overall execution and use of foreign aid, total aid disbursements amounted to $\$ 2.7$ billion during 1992-98. More than 63 percent of the aid was provided by bilateral donors, with Japan being by far the largest contributor. Free-standing technical cooperation accounted for 35 percent of the total external assistance, followed by investment project assistance, food aid/emergency and relief assistance, and budgetary/balance of payments support. While food aid/emergency and relief assistance has decreased by an average of 17 percent annually since 1992, disbursement for investment-related support has increased significantly over time. After declining sharply in 1997, external assistance has gradually recovered, and in May 2000 , donors pledged a total of $\$ 540$ million aid to Cambodia at the Consultative Group meeting.

9. The current account deficit in Cambodia is expected to widen in the near- to medium term with a recovery in the economy. Hence, private FDI is critical in providing Cambodia with much needed funds for investment. The Council for the Development of Cambodia (CDC) approved 734 FDI projects between August 1994 and 1998, with investment commitments totaling approximately $\$ 4.5$ billion. ${ }^{1}$ More than half of the investment commitments have come from ASEAN countries, followed by other Asia Pacific countries, the Americas, and Europe. While FDI largely went into the tourism and hotel industry before 1996, especially in 1995, the garment and agro-processing sectors have attracted the largest share of FDI in more recent years.

\footnotetext{
${ }^{1}$ Actual disbursement has generally been substantially lower than approvals. According to the government, this was around $40 \%$ of total approvals in 1999 , quite good by international standards.
} 
10. In 1999, the CDC approved 95 foreign investment projects with total capital commitment of $\$ 470$ million, which were more than 23 percent lower in dollar terms compared with 1998. This decline reflects lower investment in the garment sector following the imposition of garment quotas in January 1999, and ongoing difficulties amongst regional investors in the aftermath of the Asian crisis. Lack of a land law, high utility costs, inadequate infrastructure, and excessive bureaucracy are the main complaints by foreign investors in Cambodia.

\section{Box II.1 National Accounts}

Cambodia's national accounts statistics continue to be very weak. Data for many sectors have not been collected systematically since 1989 when the statistical reporting system all but broke down with the abandonment of central planning. As a basis for revising the national accounts, a Survey of Industrial Establishments and a Socio-Economic Survey were conducted in 1993-94. The authorities have now formed a national steering committee to improve statistics, with help from the Asian Development Bank (AsDB), which has recently expanded its assistance after a significant disruption during the disturbances of 1997-98. With the assistance of the AsDB, the National Institute of Statistics published national accounts data for 1993-98 in May 1999 and recently released revised data together with estimates for 1999. Estimates for GDP are compiled for constant price and current price series using both production and expenditure shares.

Assessments of economic performance are further complicated by difficulties in measuring economic activity in the burgeoning informal sector. Most households supplement their income from wage employment or agricultural activities with some form of private enterprise. Informal sector activity is widespread in both rural and urban areas. Data from the Socio-Economic Survey of 1993/94 indicate that rural households derive about 40 percent of their income from micro-enterprise activities, whereas about two thirds of the urban population is active in the informal sector.

Source: National Accounts of Cambodia 1996-1999, National Institute of Statistics, Ministry of Planning, 2000. 


\section{FisCAL REForm AND REVENUE MobILIZATION}

\section{A. Overview}

1. The current level of fiscal revenue in Cambodia, measured as a ratio to GDP, is one of the lowest in the world. Cambodia has not had sufficient resources to allocate funds to recurrent expenditure to improve government service or to finance mounting development needs in the social sector such as education, health, and public infrastructure. This chapter provides a background on recent fiscal developments in Cambodia, with a particular focus on revenue issues. In section B, fiscal developments since 1992 are examined. In section C, Cambodia's revenue structure is compared with other countries' structure, and in section D, its weaknesses and reform agenda are summarized.

2. Cambodia's efforts to establish a fiscal revenue system were initiated from extremely low levels of revenue collection. Under the socialist regime in the $1980 \mathrm{~s}$, a modern taxation system did not exist. In the early 1990s, fiscal revenue stood at only 4-6 percent of GDP, while expenditure exceeded revenue by 4-5 percent of GDP (Chart III.1). With limited flows of external financing, the government's recourse to central bank financing averaged 34 percent of GDP annually, leading to hyperinflation of over 100 percent.

3. The first credible steps toward revenue reform were made during 1992-94, which succeeded in eliminating central bank financing, and led to improved macroeconomic stability. In 1992, a major fiscal reform was initiated with assistance from foreign experts (including the IMF), followed by a significant effort in revenue mobilization by the new government formed after the UN-sponsored free election in 1993. The introduction of comprehensive revenue enhancing measures sharply increased revenue to 9 percent of GDP by 1994. Together with substantial external concessional financing, there was no need for recourse to central bank financing (until 1998), and fiscal policy played a central role in maintaining macroeconomic stability.

4. During the mid-1990s, little further progress was made in revenue reform, amid increasing political uncertainty. Several attempts were made between 1995 and 1998 , including introduction of new tax measures and reform in tax administration, but all of these efforts were essentially undermined by political intervention and an overall deterioration in governance.

5. Efforts at fiscal reform have resumed since late 1998. The new government formed after the July 1998 election has initiated important revenue measures including the introduction of the VAT. Consequently, total revenue increased beyond 11 percent of GDP in 1999. Progress has also been made in re-directing spending from defense and security to the social sectors.

6. Despite these efforts, fiscal revenue ratios-especially for tax revenue-remain among the lowest in the world (Table III.1). A major problem lies in the weak revenue structure. Cambodia relies heavily on international taxes with customs duties, export duties, VAT on 
imports, and excises on imports, generating more than 80 percent of tax revenue (Chart III.2). After joining ASEAN in early 1999, Cambodia started reforming customs tariffs in line with the AFTA agreement. This will require Cambodia to make further efforts in seeking revenue enhancing measures to offset expected reductions in customs duties in the near future.

7. The government faces severe constraints in implementing its expenditure policy because of low revenue. For most of the period 1994-99, domestically financed expenditure remained at 9-10 percent of GDP. With defense and security spending accounting for 40-50 percent of domestically financed expenditure, social sector spending and locally financed capital expenditure have been limited. To fulfill development needs, Cambodia relies almost entirely on external grants and concessional loans to finance its public investment programs; 80 percent of capital expenditure was financed by external resources during 1994-99 ${ }^{1}$.

\section{B. Fiscal Development Since 1992}

\section{Fiscal developments between 1992 and 1994}

8. The government made comprehensive reforms in mobilizing revenue during 1992-94. Revenue mobilization was one of the main objectives of the overall fiscal reform agenda, and a major effort was initiated in 1992 with assistance from the IMF and UNDP. The reform program covered all aspects of Cambodia's revenue system in tax policy and tax and customs administration. These efforts were rewarded by a significant revenue increase in 1994; total revenue increased to 9.5 percent of GDP compared to 4.4 percent in 1991, well beyond the initial reform targets ${ }^{2}$. Under the Organic Budget Law, introduced in December 1993, domestically financed expenditure was contained within budget estimates, and central bank financing was eliminated for the first time since the late 1980 s when Cambodia started moving from a centrally planned economy to a market oriented economy.

9. Among the various reform measures taken during this period, the most effective were in improving international taxes, customs administration, and forest revenue, whereas domestic tax collections did not improve as much as had been expected mainly because of delays in implementing measures related to wage and profit taxes. Revenues from international taxes and the forestry royalty were almost nil in 1991, but both of them increased by about 5 percent and 1 percent of GDP, respectively, by 1994 . These successful . measures included:

\footnotetext{
${ }^{1}$ A considerable amount of externally financed capital projects are executed outside the government budget by donors and NGOs. Hence, the figure reported in the budget data understates the actual amount of externally financed capital projects.

${ }^{2}$ Actual revenue collections in 1994 exceeded targets under the previous ESAF supported program, and actually exceeded the targets that had been set for 1996 under the program ( 9.1 percent).
} 
- Introduction of a new tax. The business tax on imports was replaced by a consumption tax on imports in September 1993. The consumption tax had a much simpler structure with an ad-valorem tax rate of 4 percent levied on the duty-inclusive value of all dutiable imports. The new tax generated revenue of about 1 percent of GDP in 1994.

- Increases in tax rates. The duty rate on petroleum products was increased gradually from 3-5 percent in 1992 to 50 percent in 1994 along with an increase in the administratively set dutiable values. As a result, import duties from petroleum products increased from virtually zero in 1991 to about 1 percent of GDP in 1994.

- Improved customs administration. A reform of customs administration was a core of the fiscal reform, resulting in significant increase in customs duties, up from $1 \frac{1}{2}$ percent of GDP in 1991 to $4 \frac{1}{2}$ percent in 1994. The steps taken included: (i) the adoption of a general tariff based on the harmonized system of classification, together with the rationalization of the tariff structure (including the elimination of discounted tariff rates for selected countries), (ii) the adoption of an invoiced-based system for valuation of customs duties, and (iii) the adoption of an anti-smuggling task force.

- Increased revenue from the forestry sector. A log export ban, which had been imposed since September 1992, was temporarily repealed in October 1993, resulting in an unsustainable increase in logging activity. However, the export ban was re-imposed in May 1995, and together with a deterioration of governance, revenue performance in the forestry sector deteriorated considerably after 1994.

\section{Fiscal developments between 1995 and 1998}

10. Following this initial progress, revenue mobilization during 1995-98 stagnated with total revenue not exceeding 9-10 percent of GDP. In particular, between mid-1997 and late 1998 , the government faced serious difficulties in managing fiscal policy. Shortfalls in revenue collection, and difficulty in restraining military and security expenditure led the government to use central bank financing of the budget in 1998 for the first time since 1994.

11. During this period, several attempts were made to further enhance fiscal revenue, and a total revenue target of 11 percent of GDP for 1998 was set by the government ${ }^{3}$. To achieve this objective, the government's efforts focused on enhancing tax revenue by introducing a new tax, increasing tax rates, and broadening the tax base, especially in the area of domestic taxes. In addition, attempts in improving tax and customs administration were continuously made.

\footnotetext{
${ }^{3}$ Under the second annual arrangement under the previous ESAF (requested in 1995), the government's target was to increase revenue to 10 percent of GDP by 1997 , and under the third annual arrangement (requested in 1997), to 11 percent of GDP by 1998.
} 
- In 1995-96, the government introduced several new taxes and increased tax rates on existing taxes ${ }^{4}$. New tax measures included (i) the introduction of a tax on wages, (ii) the introduction of a 20 percent excise tax on gasoline, and (iii) the introduction of an ad-valorem export tax on rubber.

- Efforts to improve tax and customs administration included: a establishment of a Large Enterprises Administration Bureau in the Tax Department of the Ministry of Economy and Finance (MEF) ${ }^{5}$, a computerized database of large taxpayers, and launching pre-shipment inspection (PSI) for imports in 1995.

- In 1997, to further improve tax policy and strengthen tax administration, the National Assembly adopted a new Law on Taxation. The law included: (i) extension of the coverage of wage and profit taxes, (ii) inclusion of the first sale of import goods into the turnover tax, (iii) replacement of turnover and consumption taxes for incorporated business with a VAT, (iv) reinforcement of the authority's power on taxpayer investigation and tax collection, (v) introduction of "Charter of Taxpayers Rights and Obligations," and (vi) reinforcement of a penalty clause.

12. However, almost all of these reform attempts were undermined by a lack of political will or deterioration in governance. The authority of the MEF was contravened by line ministries, undermining the effectiveness of revenue collection. The implementation of most of the critical tax policy measures included in the 1997 Law on Taxation was postponed or neglected; for example, the implementation of the VAT was postponed until January 1999. More seriously, fiscal policy was affected by conflict over power sharing between the two main coalition parties, and military interference. These resulted in widespread ad-hoc exemptions of tax and customs duties, extensive smuggling, a significant loss in forest revenue, and increased arrears problems in both tax and non-tax revenue.

\section{Fiscal developments in 1999}

13. Fiscal performance improved considerably in 1999. Total revenue increased by 2.5 percentage points to 11.5 percent of GDP. With well-restrained expenditure, the government's net debt with the central bank was reduced by 0.6 percent of GDP in 1999 .

14. A significant increase in revenue was primarily accounted for by implementing measures that had already been included under the 1997 Law on Taxation, such as the VAT. Discipline in fiscal policy management was also improved by strictly avoiding ad-hoc tax

\footnotetext{
${ }^{4}$ It was projected that these measures would generate revenue of 1.5 percent of GDP on an annual basis.

${ }^{5}$ Previously, responsibilities for the tax assessments, audits, and collection were scattered among various departments in the MEF, resulting in a complicated administration structure that undermined efficient tax collection. The responsibility of this Bureau is to manage the real regime, which covers all incorporated businesses in Cambodia. The Bureau closely administers the tax return, conducts tax audits, and verifies compliance with tax laws.
} 
and customs duties exemptions. In addition, an effort was made in strengthening the MEF's authority to collect non-tax revenues from line ministries, as evidenced by the timely transfer of funds associated with the garment quota auction revenue. More specifically:

- Strong performance of the VAT introduced in January 1999 led to an increase in tax revenues by 1.8 percent to 8.3 percent of GDP, even higher than the initial budget projections by 0.9 percent of GDP. The VAT, which replaced the turnover tax for incorporated businesses and the consumption tax for imports, has a uniform rate of 10 percent, with a much wider tax base (Box III.1).

- Customs revenue increased by 0.2 percent of GDP compared to 1998, reflecting the reduction in ad-hoc tax and import duty exemptions. At the beginning of the year, the government re-imposed customs duties on steel, cement, and automobiles, and reintroduced the export taxes on rubber and sawn timber. In June, the regulation regarding foreign investment was amended to reduce the scope for tax incentives for foreign investors, and in September, complex import duties on cigarettes were unified.

- Non-tax revenues increased by 0.9 percent of GDP, reflecting efforts made to collect garment quota and forestry revenue in a transparent manner. Following the bilateral textile agreement with the U.S. ${ }^{6}$, the Ministry of Commerce conducted three auctions to allocate garment quotas among garment factories. Together with the introduction of the auctions, the government imposed a quota management fee and a garment export license fee on these factories. As to forestry revenue, the timber royalty was raised to US\$ 54 per cubic meter at the beginning of the year, and maintained at this level for the rest of the year. The increase in the timber royalty served to maintain forestry revenue at the 1998 level despite a sharp reduction in the volume of logging.

15. However, in other areas of non-tax revenue, only limited progress was achieved in improving collections. Although effort was made in improving the timely transfer of revenue from the sale or lease of state-owned assets to the treasury, the government continued to experience recurring arrears from telecommunications, enterprise and immobile leases, civil aviation, and visa fees, partly due to a lack of an effective and transparent system of non-tax revenue collection. Moreover, it was clear that government's announced intention to bring all contracts involving the use of state assets (including intangible assets) under the control of the MEF was not strictly being followed.

\footnotetext{
${ }^{6}$ In January 1999, the United States and Cambodia reached agreement on a new bilateral three-year textile agreement under the Generalized System of Preferences of the United States. This agreement contains a labor provision, and Cambodia is able to receive an annual quota increase of 6 percent plus an additional increase of 14 percent (at a maximum) if the United States finds that Cambodia is in substantial compliance with its labor laws and internationally recognized core labor standard. In May 2000, it was announced that the United States awarded an additional 5 percent garment quota increase in recognition of progress made by Cambodian government in the enforcement of the labor standards.
} 


\section{Box III.1. Reform in Indirect Tax System in Cambodia-Introduction of the VAT}

\section{The VAT system in Cambodia}

In January 1999, the VAT was implemented to replace the turnover tax and consumption tax on imports. The VAT covers all incorporated businesses that are registered under the "real regime ',"which are carried out by the Large Enterprises Administration Bureau of the Tax Department located in Phnom Penh, and since the beginning of 2000, in five major provincial offices. In May 2000 , the coverage was further widened by extending the VAT registration to 500 additional firms. As a result, revenue from the VAT in 2000 is expected to increase to 2.9 percent of GDP. The Cambodian VAT has a simple structure and a uniform tax rate of 10 percent. The main features of the system include: (i) covering both goods and services, (ii) including all stages of importation, production, and distribution, (iii) self-assessment and monthly payment, (iv) zero rates only for the export of goods, and services rendered abroad, (v) a small range of exemptions, (vi) no credit allowance for the VAT paid for entertainment services, automobiles, and certain petroleum products, and (vii) an accommodative refund system of excess tax credit to exporters and investment enterprises. $^{2}$

The VAT has served not only to enhance revenue, but also to improve the efficiency of the tax system, by simplifying the tax structure, widening the coverage and reducing cascading, which were major shortcomings under the previous turnover and consumption taxes.

- Simplifying tax structure: The turnover tax was unnecessarily complex. There were 3 different tax rates of 1 percent, 4 percent and 10 percent, and in some cases, taxpayers had to pay tumover tax at different rates on different parts of their turnover. On the contrary, the VAT uses a uniform rate of 10 percent, which facilitates tax administration, reduces the scope for false declarations, and helps to ensure uniformity of tax burdens on all consumer goods and services.

- Widening the coverage: The turnover tax did not apply to agricultural products sold by primary producers, mobile traders and small permanent establishments. The coverage of the VAT is much wider than the turnover tax and consumption tax, exempting only (I) public postal services, (ii) hospital and medical services, (iii) public transportation, (iv) insurance services, (v) financial services, (vi) imports for personal use exempted from customs duties, (vii) non profit activities in the public interest, and (viii) imports of goods related to diplomatic and international organization.

- Reducing cascading: Without a proper tax credit system, the turnover tax system in Cambodia suffered from cascading. The VAT is a consumption-type tax with an invoice base, and all purchased inputs of raw materials, semi-finished and intermediate goods, and capital goods at all stages of production are designed to receive full input tax credits.

\section{Scope for further improvement}

Although the performance of the VAT was satisfactory in 1999 as the first year of the introduction, there are several concerns that need to be addressed in the near term.

- The VAT registration base is poorly managed, encouraging non-compliance, and needs to be carefully reviewed. For example, as of end-Febnuary $2000,1,928$ taxpayers were registered for the VAT, but the actual number of VAT returns was only 1,473 , of which 393 were blank. There exist many enterprises who initially registered for the VAT, but never file a monthly VAT return.

- The VAT refund procedures are slow and delayed, due to unnecessary complex administrative procedures. During 1999 , the MEF expected to refund CR 33 billion of the VAT, but only CR 14 billion in refunds was made. To avoid cascading problems, and to ensure continued good compliance with the VAT, the MEF needs to review the refund procedures so that taxpayers receive legitimate refunds in a timely fashion.

In addition, although not urgent, the VAT threshold may need to be reviewed. The coverage of the real regime, which defines the base of VAT taxpayers, is defined in terms of the ownership structure of businesses. The real regime covers incorporated businesses regardless of size of turnover, but excludes unincorporated businesses, many of which may be large enterprises.

Cambodia's tax system is divided into a real regime and estimated regime under the 1997 Law on Taxation (Article 4)/ Taxpayers in the real regime are obliged to pay the VAT in lie of turnover tax, submit a tax declaration on profits based on their balance sheet and profit statements and are subject to the minimum tax.

${ }^{2}$ Exporters and importers are entitled to the immediate refund of excess tax credit, while the refunds to other taxpayers are made only if there is a net excess for three consecutive months. 
17. Expenditure policy was kept well under control. While wages exceeded the budget by 0.4 percent of GDP due to a 30 percent salary increase granted in May 1999, non-wage expenditure fell below the budget by the same amount of 0.4 percent of GDP. As to expenditure for defense and security, about 16,000 ghost soldiers and nearly 110,000 dependents who were receiving allowances were identified during 1999. Those were immediately removed from the budget, resulting in reductions in expenditure for defense after mid-19997. In addition, committed expenditure for the social sectors (health, education, and rural development) slightly exceeded budget estimates and represented a substantial increase over the 1998 level. However, this was made possible only by a rapid acceleration of the spending commitments during the last two months of the year.

\section{0 budget and developments in the first half of the year}

18. The 2000 budget emphasized the importance of increasing revenue as well as the government's intention to continue directing expenditure away from defense and security and toward the social sectors. The revenue forecast envisaged an increase of about 0.3 percent of GDP compared to the actual outturn in $1999^{8}$. However, despite the government's stated intention to enhance tax revenue, tax revenue as a percent of GDP was conservatively budgeted at the same level of 1999 actual outturn, while budgeted increase in non-tax revenue was ambitiously set at 0.3 percent of GDP with a large amount of arrears recovery expected from post and telecommunications. Current expenditure was budgeted to increase by 0.7 percent of GDP, including measures to redirect spending from the defense and security sector to the social sectors. Capital expenditure, which includes both domestically and externally financed public investment, was budgeted to increase by 1.4 percent of GDP, and the overall deficit was expected to widen by 1.7 percent to 6.1 percent of GDP. However, the current balance was budgeted to remain in surplus at 1.4 percent of GDP, and with increasing foreign financing, the government's net debt position with the central bank would improve further.

19. For the first half of 2000 , overall budgetary developments were broadly consistent with the approved budget. After some shortfalls early in the year, total revenue has been increasing in line with the government's forecast, with increases in revenues accounted for more by increases in tax revenue rather than non-tax revenue. The expenditure program has been implemented with careful attention to the government's financing targets.

- On the revenue side, overall performance was broadly consistent with the budget mainly owing to strong performance of the profit tax and the VAT. The MEF extended

\footnotetext{
${ }^{7}$ Expenditure savings due to the removal of ghost soldiers and dependants are estimated to be about $1 / 2$ percent of GDP on an annual basis.

${ }^{8}$ Excluding revenues from garment quota auction, which raised exceptional revenue of 0.8 percent of GDP in 1999, the underlying revenue increase was about l percent of GDP.
} 
- the real regime system to five additional provinces, which resulted in an increase in the profit tax and VAT collections. Revenues from direct and indirect taxes are now expected to exceed the initial budget projection, offsetting some shortfalls in revenue collections from trade tax and non-tax revenue items. The slowdown in trade tax started in the last quarter of 1999 reflects declines in cigarette imports, which accounted for nearly 20 percent of customs duties revenues in 1999 (Chart III.3)

- On the expenditure side, overall current expenditure is well under control, although full implementation of the budget for the social sectors will require an acceleration in spending during the second half of the year. Total expenditure for education, health, and rural development in the first half of the year was only 30 percent of the initial budget. The execution of spending has been affected by technical difficulties in implementing the budget by the line ministries ${ }^{9}$. Further, improvements in spending will require a strengthening of institutional procedures described (see Box III.2).

\section{International Comparison of Revenue Performance}

20. Some insight into revenue potential can be obtained by comparing the revenue structure in Cambodia with that in comparable low-income countries, including other post conflict countries. Fiscal revenue may be negatively affected by low per capita GDP, high dependency on the agriculture sector, a large informal sector, and an unstable political and social situation. All of these are applicable to the current situation in Cambodia. Table III.1 provides some comparisons with PRGF countries in Asia and Sub-Saharan Africa. The facts observed in the table are:

- While there is a tendency for the tax revenue ratio to correlate positively with per capita GDP, Cambodia's tax revenue ratio is even below other low-income countries'. Cambodia (an average of 6.3 percent of GDP in 1995-98) is lower than Nepal (8.8 percent), Mali (12.6 percent), Tanzania (11.5 percent), and selected post conflict countries (10.6 percent), although per capita GDP in Cambodia is higher than all of these countries.

- Similarly, while high dependency on agriculture tends to constrain revenue collection $^{10}$, the ratio in Cambodia is lower than in other comparable agriculture dependant countries. For example, agriculture in Lao P.D.R., Nepal, Cameroon, Mali,

\footnotetext{
${ }^{9}$ In part, this reflects the fact that the line ministries were occupied with executing the large budget allocations carried over from the last two months of 1999.

${ }^{10}$ The agriculture sector is considered to be difficult to tax due to many reasons: inefficiency in collecting taxes from large numbers of small farmers, difficulty in measuring taxable values or incomes, and social reluctance in taxing subsistence goods. In addition, in case of Cambodia, the lack of legally clear land ownership reduces the possibility to effectively collect revenues from this sector, which may be one of the explanations for Cambodia's low revenue ratio compared to other agricultural countries.
} 


\section{Box III.2. Improving Government Spending to the Priority Sectors}

Government spending on basic health and education services in Cambodia is among the lowest in the world. To make lasting reductions in poverty, particularly in rural areas, it will be necessary to improve the delivery of these essential services, as well as to increase spending for agriculture and rural development. The PRGF program targets a re-orientation of budgeted resources toward the priority sectors and away from defense, security, and other public activities.

To re-orient expenditure, as part of the $\mathrm{PRGF/SAC}$ programs, the government has prepared medium-term expenditure targets covering 1999-2002 for the four priority areas (agriculture, rural development, health, and education). The share of government spending for the four priority sectors would increase from 23 percent to 32 percent, while defense and security would fall from 42 percent to 29 percent. The government has committed to meet the annual budgetary targets for these sectors, with a more equal allocation of spending during the course of the year. Under the program, should revenue deviate in a significant way from projections, adjustments would be made in a manner that favors the priority sectors (i.e., the ratio of actual to budgeted expenditures for the priority areas will be at least as high as for the remaining parts of the budget).

The World Bank is supporting institutional changes to improve the delivery of government services. Priority Action Programs (PAP) will protect critical expenditures for such programs as primary education, basic health, and rural roads from possible revenue shortfalls. Health spending will also be enhanced by the use of the Accelerated District Development program which is an advance payment system to ensure timely disbursement to district health centers. Finally, with effect from the 2000 budget, a Budget Strategy and Enforcement Center (BSEC) has been created in the Ministry of Economy and Finance. The establishment of the BSEC, which is still in the very early stages, is expected to improve the operational efficiency of expenditure by avoiding slow and irregular disbursement of funds, and streamlining the budget execution procedures in implementing the PAP. Continued strong efforts by the authorities, supported by technical assistance, will be necessary to make the BSEC fully operational.

\section{Recurrent Spending on Health and Education \\ (Commitment basis; in percent of GDP)}

$\begin{array}{cccc}\text { Cambodia } & 1998 & 1999 & 2002 \text { (target) } \\ \text { Health } & 0.4 & 0.7 & 1.1 \\ \text { Education } & 0.9 & 1.3 & 1.8\end{array}$

Low-income Countries $1 /$

Health

Education

2.7

1/ Fund staff estimates based on a sample of 23 PRGF and PRGF-eligible countries. 
and Tanzania accounts for more than 40 percent of GDP, compared to Cambodia's agriculture share of 39 percent, but the tax revenue ratio of all these countries exceeds that of Cambodia.

- Post conflict countries (such as Burundi, Congo Dem., Ethiopia, Mozambique, Rwanda, Sierra Leone, and Uganda, which suffered from repeated internal and political instability) have difficulty in generating fiscal revenue ${ }^{11}$. The revenue ratio is lower in Cambodia than in all of these post conflict countries except Democratic Republic of the Congo and Sierra Leone.

- In Cambodia, the level of non-tax revenue in comparison with tax revenue is among the highest. Cambodia's non-tax revenue is equal to 43 percent of tax revenue, much higher than similar Asian countries (26 percent) and Sub-Saharan African countries $(23 \text { percent })^{12}$. This reflects the low level of tax revenue in Cambodia.

21. A positive correlation between tax revenue and per capita GDP may partly reflect the fact that low-income countries generally suffer from a limited size of the formal sector--which is relatively easy to tax---and governance problems. For most poor countries in the table, the formal sector is limited to the public sector, natural resource extraction (such as mineral and petroleum), and large manufacturing and retail establishments. This reduces the scope for the domestic tax base. Accordingly, these countries have a tendency to rely more on trade taxes than domestic taxes. Cambodia also depends highly on trade taxes, which reflects the fact that (i) most large manufacturing and retail businesses in Cambodia benefit from tax exemptions under the Law on Investment, and (ii) extensive tax erosions prevail due to governance problems and weak enforcement by the authorities. In addition, as in most low-income countries, governance problems are aggravated by poorly trained tax and customs officials, weak management, low salaries, inadequate equipment and supplies, as well as insufficient tax and customs legislation.

22. In sum, international comparisons reveal that there is considerable scope for improving Cambodia's fiscal revenue. While revenue potential for Cambodia may be limited due to low per capita GDP, high dependency on the agriculture sector, limited scope of the formal sector, and the legacy of past history, large numbers of other developing countries that are in a similar development stage, and have a similar experience of political and social problems, generate higher fiscal revenue than Cambodia. In fact, Cambodia's tax revenue

"Given that tax collection process requires highly efficient administration skills in registering taxpayers, collecting taxes, enforcing tax collection, auditing, and encouraging taxpayers to comply with tax legislation, loss of administration skills due to war is damaging.

${ }^{12}$ In case of non-tax revenue, there is not a clear correlation with other development indicators. Non-tax revenue seems to be more volatile and more dependent on country specific factors. High level of non-tax revenue in Cambodia partly reflects that tax revenue is too low. 
ratio in the 1960s, before the war and internal conflict period, was much higher at 13-15 percent of GDP than that in the present ${ }^{13}$.

\section{Existing Weaknesses and Reform Agenda}

23. The recently improved revenue performance has been largely accounted for by the successful introduction of the VAT. Further comprehensive reform in the revenue system is essential for enhancing growth and alleviating poverty in Cambodia. The following summarizes underlying weakness in the current fiscal revenue system and the reform agenda.

\section{Narrow tax base}

24. As emphasized above, Cambodia's tax base is extremely narrow compared to other countries, and needs to be broadened. Nearly half of tax revenue is collected from international taxes, and more than 75 percent of this revenue is accounted for by a limited number of import items ${ }^{14}$. More effort needs to be made to expand both the domestic and international tax bases. In this context, issues that need to be addressed include:

- Effectiveness of direct taxes (profit tax and wage tax). Revenue from direct tax accounted for only 8.6 percent of total tax revenue in 1999 . One of the factors that explain the ineffectiveness of these taxes lies in the level of exemptions. For example, with a threshold of CR 6 million of annual turnover for the profit tax, more than 90 percent of companies filing turnover tax returns can be exempted from the tax. With the monthly income threshold of CR 500,000 for the wage tax-about six times per capita GDP-the tax is withheld from only 6,500 employees in the whole country. However, increasing the scope of direct taxation can only be done commensurate with improvements in tax administration.

- Generous tax incentives under the Law on Investment. The provisions under the Law on Investment regarding profit tax and customs duty exemptions extremely limit the scope of the tax base and the scope of dutiable imports ${ }^{15}$. Currently, half of total imports are not dutiable, and apart from foreign aid-related imports, the majority of exemptions (about 70 percent of total exempted imports) are made under the Law on Investment (Box III.3).

${ }^{13}$ See Rémy Prud'homme, 1969.

${ }^{14}$ Cigarettes, motorcycles and spare parts, vehicles and spare parts, and petroleum products.

${ }^{15}$ Investors can benefit from exemptions of profit tax of up to eight years beginning from when the project derives its first profit. For customs duties, 100 percent exemption for capital goods and raw materials is allowed. 


\section{Box III.3. Revenue Structure of Customs Duties and Law on Investment}

\section{Structure of customs duties}

In 1999, 80 percent of tax revenues were collected by the Customs and Excise Department of the MEF (customs duties, export duties, VAT on imports, and excises on imports). Customs duties account for more than half of these international tax revenues, and although tariff rates are gradually declining in line with AFTA requirements, revenue from customs duties is still expected to be an important resource in the short and medium term, at least until domestic tax collections improve. Revenue potential from customs duties would be even greater if not for the narrow scope of dutiable goods.

In 1999 , only 56 percent of total imports were subject to customs duties, and the rest were exempted (Chart III.3). About $3 / 4$ of total customs duties were collected from a limited number of dutiable goods, i.e. cigarettes, cement and steel, garments, motorcycles and vehicles, and petroleum products. Due to the narrowness of the dutiable base, customs duties are vulnerable to fluctuations in import values and volumes for these limited goods. In fact, in the last three months of 1999 , revenue from customs duties dropped significantly, reflecting substantial declines in recorded imports of cigarettes and petroleum products, due in part to increased smuggling. Imports of petroleum products seem to have increased recently, but imports of cigarettes continue to be low, reflecting a decline in re-export trade to neighboring countries.

\section{Law on investment}

One of the reasons for the weakness in the structure of customs duties lies in the provisions under the 1994 Law on Investment, which provide generous tax incentives to investors.

The authorities have committed to rationalize the tax incentive scheme. In December 1997, faced with serious problem of tax erosion due to extensively granted tax and customs duties exemptions under the law, the government implemented Sub-decree 88, which: (i) limits the scope of exemptions for profit tax and customs duties, (ii) clarifies the scope of investment activities that are eligible for the exemptions, (iii) requires all enterprises granted a 9 percent reduced tax rate to prepay profit tax, and (iv)requires all enterprises regardless of profit tax exemptions to pay the minimum tax. In June 1999, to further limit the scope of tax incentives, the sub-decree was amended. Major changes are (i) raising the minimum investment capital of selected investment sectors (such as garments), (ii) removing production of consumption goods and exploitation of minerals and industrial equipment from the list of selected investment sectors, and (iii) specifying that imports of all kinds of fuel, lubricants and other petroleum products are not subject to customs duty exemptions.

There has been some progress in rationalizing the tax incentive schemes to reduce the extent of tax erosions, but the measures taken so far have not sufficiently improved revenue performance. While various tax incentives are provided in all neighboring countries, several features of the Law on Investment provide overly generous incentives compared to these countries. For example, (i) tax holidays are permitted up to eight years, (ii) profits are taxed at a reduced rate of 9 percent (instead of the normal rate of 20 percent) after the end of the holiday period, (iii) reinvestment of profits is tax free, and (iv) repatriation of earnings and other incomes is tax free. Under the PRGF and the World Bank SAC programs, the government is committed to further revise the Law on Investment to rationalize tax and customs duty exemptions. 


\section{Weak tax administration}

25. It is critical to strengthen tax administration capacity so that domestic taxes can be collected effectively and in a transparent manner. Major problems include:

- Non-compliance and tax arrears problems under the "real regime." In 1999, the MEF conducted an audit for about 300 enterprises (pertained to 1995 and 1996 tax years), and almost all of these cases were found to be subject to penalties, raising a major concern about non-compliance ${ }^{16}$. A comprehensive improvement will be necessary in all areas of administration, such as verification, cross-checking, compilation of appropriate data, research and analytical skills, and auditing.

- Highly discretionary tax assessments under the "estimated regime." Under this regime, tumover tax is estimated by individual tax officials in consultation with the taxpayer, and profit tax is calculated based on this estimated turnover tax. There is neither computerization for data compilation nor adequate independent internal audit, spot-checking and explicit sanctions in cases of corruption.

- Delays in VAT refund approvals. In some case, it could take about a year to refund the VAT collected to taxpayers, which may result in discouraging taxpayers to comply with the tax obligation. This could reflect a failure of taxpayers to submit sufficient documentation. Alternatively, bureaucratic and inefficient procedures of the tax authorities could also slow the processing of refunds. Implementation of a credible refund system is essential for sustaining the VAT.

- Lack of strategic tax payer education. There is almost no effort at taxpayer education or consultation, and many taxpayers are not familiar with the current tax system.

\section{Weak customs administration}

26. Customs administration suffers from fundamental weaknesses in all major aspects. With a porous border, smuggling is a continuous problem, and the potential revenue loss could be enormous. Given the importance of revenue from intemational taxes, while waiting for the development of the domestic economy to generate more domestic tax revenue, strengthening of customs administration is essential for overall revenue enhancement. There are several areas to be addressed:

- Outdated legislation. The current basic legislation 1989 Law on Imported and

${ }^{16}$ Even the VAT, which was considered to be successfully introduced, suffers from noncompliance problems. For example, although approximately 2,000 companies are registered as VAT taxpayers (as of end-March), only about 1,500 companies are filing VAT returns. 
Exported Goods is very limited in scope, and the law includes provisions that are inconsistent with modernization of customs procedures. These deficiencies in the law include the requirement for every import to be physically checked, inadequate valuation provisions, lack of provisions for computerization, and inadequate penalty provisions $^{17}$.

- Limited human resources. The current human resources are extremely weak, and levels of technical customs knowledge and managerial skills need to be improved. ${ }^{18}$.

- Poor infrastructure. The current computer hardware and software are slow and outdated, and prevent the authorities from compiling an accurate and informative database. The material infrastructure, including offices, and enforcement aids (e.g. patrol vehicles), also need to be improved.

- Complex customs control. While the Customs and Excise Department has the main responsibility over custom controls, other government agencies, notably the Ministry of Commerce and the Ministry of Interior, engage in customs controls. This duplicative control raises concerns about transparency and efficiency in customs procedures.

- Necessity of PSI. Until the administrative and enforcement capabilities of the customs administration are strengthened, the recent reinstallation of pre-shipment inspection for imports should help sustain revenue performance. With the PSI system, customs revenue could be raised by improving the accuracy of reporting of customs value, and customs administration could be further strengthened by the transfer of skills and knowledge from the PSI service provider.

${ }^{17}$ Currently, the customs code is being amended and is expected to be finalized soon.

${ }^{18}$ Currently, the customs department is introducing measures such as (i) rotating customs officials periodically to reduce irregularities, (ii) enacting tough discipline and measures against customs officials in violation of the customs code, and (iii) building capacity through training with assistance from other countries. 


\section{References}

Abed, Greorge, T., and others, 1998, "Fiscal Reforms in Low-Income Countries Experience under IMF-Supported Programs," IMF Occasional Paper No. 160 (Washington: International Monetary Fund).

Burgess, Robin, and Nicholas Stern, 1993, "Taxation and Development," Journal of Economic Literature Vol. XXXI, pp. 762-830.

International Monetary Fund, 1997, "Cambodia: Recent Economic Developments," IMF Staff Country Report No. 97-9 (Washington: International Monetary Fund).

Prud'homme, Rémy, 1969, "L'Économic du Cambodge," Presses Universitaires de France.

Stotsky, Janet G., and Asegedech WoldeMariam, 1997, "Tax Effort in Sub-Saharan Africa," IMF Working Paper 97/107 (Washington: International Monetary Fund).

Tanzi, Vito, and Howell H. Zee, 2000, "Tax Policy for Emerging Markets: Developing Countries," National Tax Journal Vol. LIII, pp. 299-322.

World Bank, 1999, "Cambodia: Public Expenditure Review," (Washington: World Bank) 
Table III. 1 Cambodia: Comparison of Tax Revenue Structure with Other Selected Countries

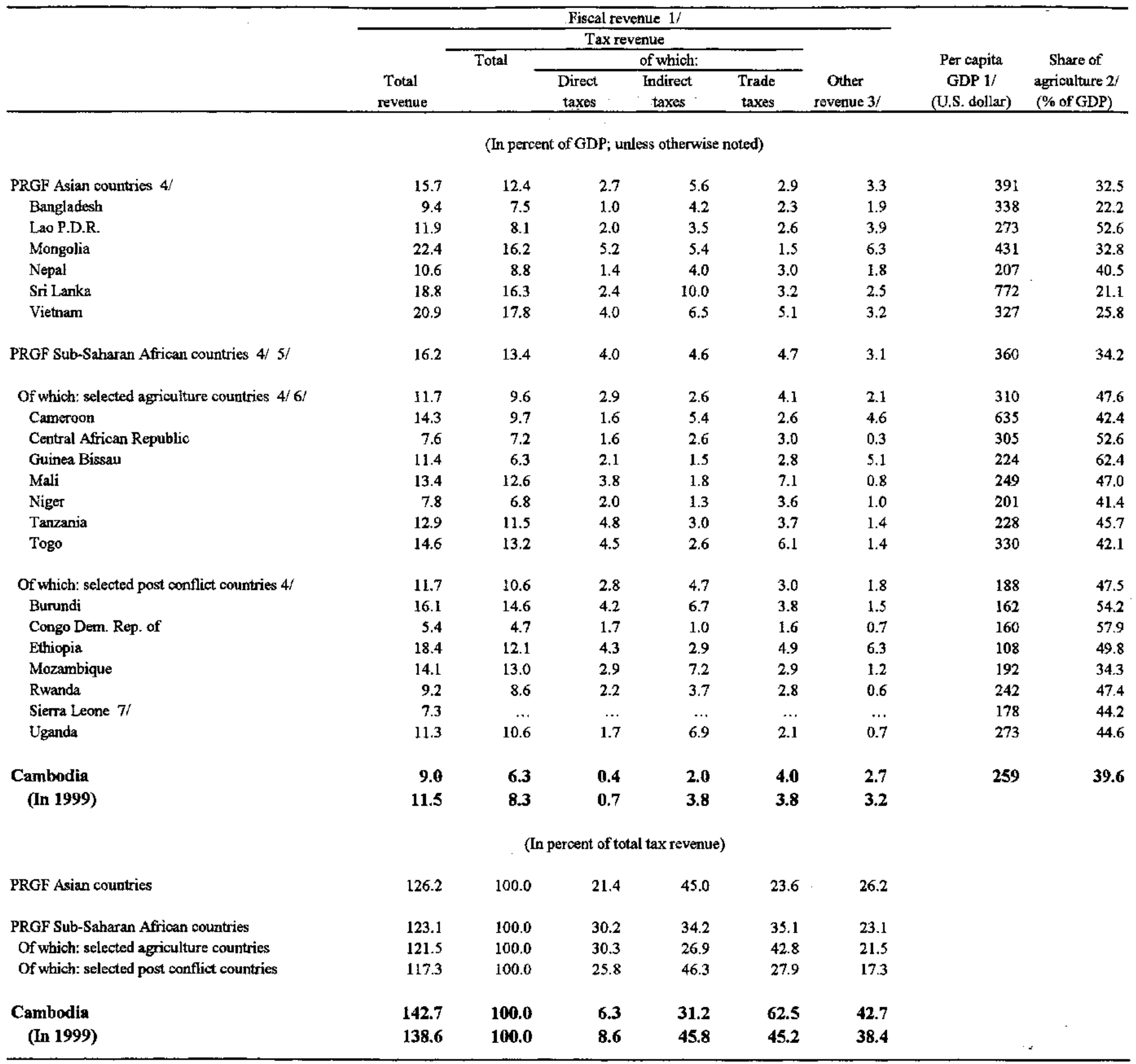

Sources: IMF, Tax Policy Handbook, Government Finance Statistics, International Financial Statistics, Recent Economic Development, Statistical Annex; and World Bank, World Development Indicator.

1/ Data refer to average of $1995-98$ or 1995-97, unless otherwise indicated.

2/ Data refer to 1998.

3/ Other revenue includes non-tax revenue and capital revenue.

4/ Unweighted average of sub-group countries.

5/ The sample includes Benin, Burkina Faso, Burundi, Cameroon, Central African Republic, Chad, Comoros, Congo Dem. Rep. Of, Congo Rep. Of, Cote d'Ivoire, Djibouti, Ethiopia, Gambia, Ghana, Guinea, Guinea Bissau, Kenya, Lesotho, Madagascar, Malawi, Mali, Mauritania, Mozambique, Niger, Rwanda, Sao Tome and Principe, Senegal, Sierta Leone, Sudan, Tanzania, Togo, Uganda, Zambia, and Zimbabwe.

6/ Based on agriculture share as a percentage of GDP larger than 40 percent, excluding those classified under selected post conflict countries.

7/ Data refer to 1998. 
Chart III.1 Cambodia: Fiscal Development, 1990-2000 (in percent of GDP)

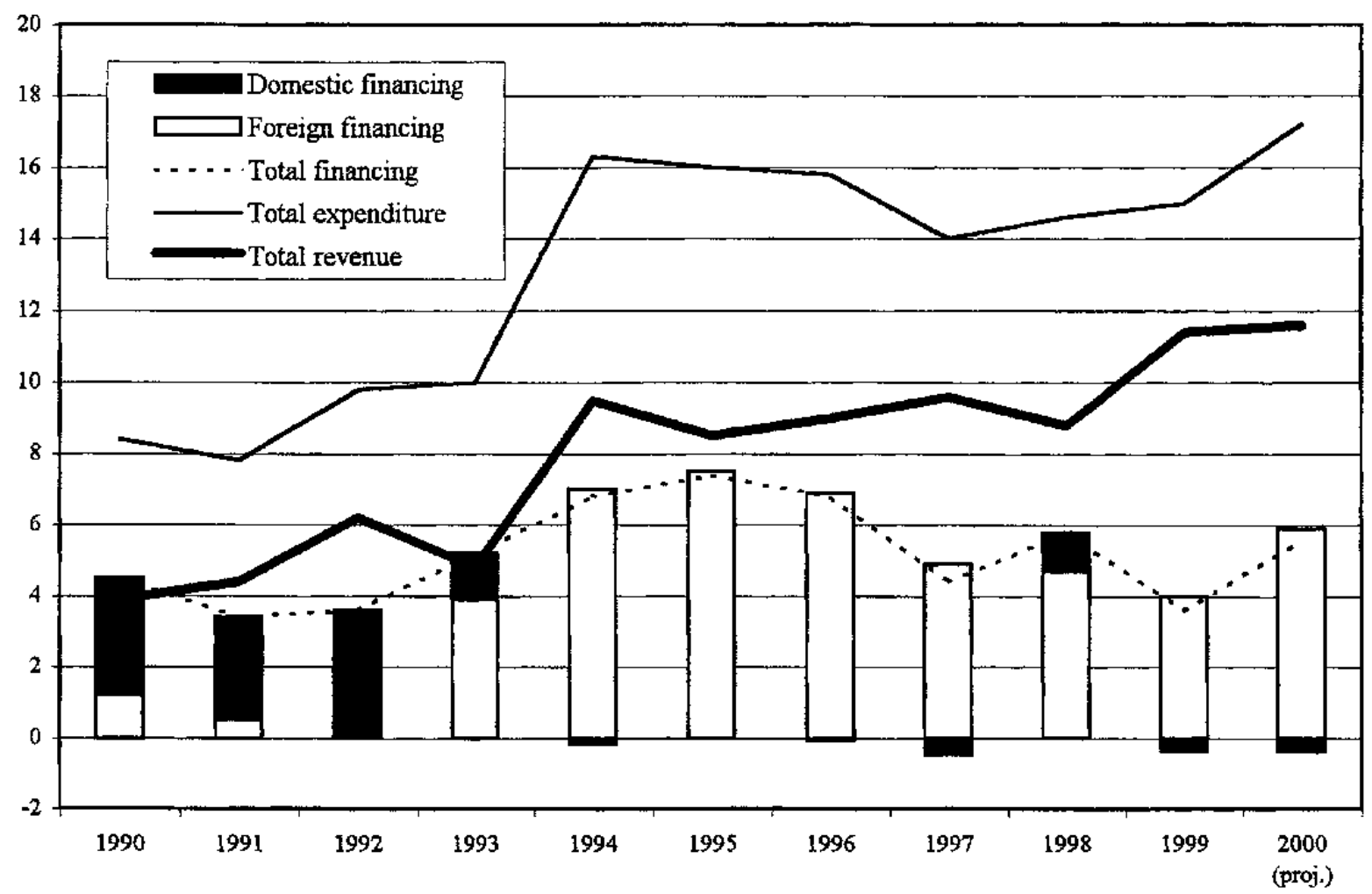

Source: Data provided by Cambodia authorities, and Fund staff estimates and projection. 
Chart III.2 Cambodia: Current Revenue and Domestically Financed Expenditure, 1994-2000 ( in percent of GDP)

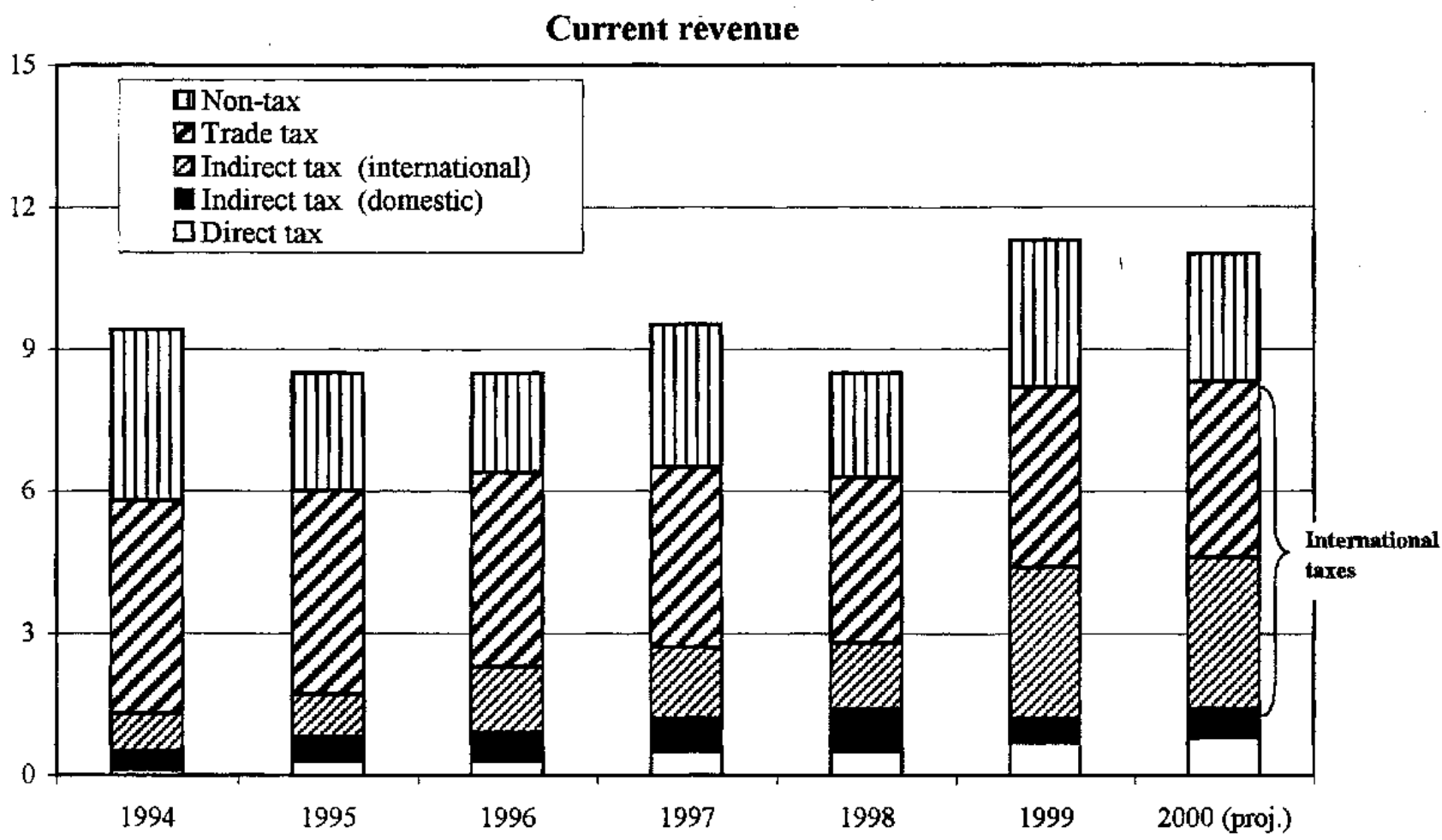

Domestically financed expenditure

(Current and locally financed capital expenditure)

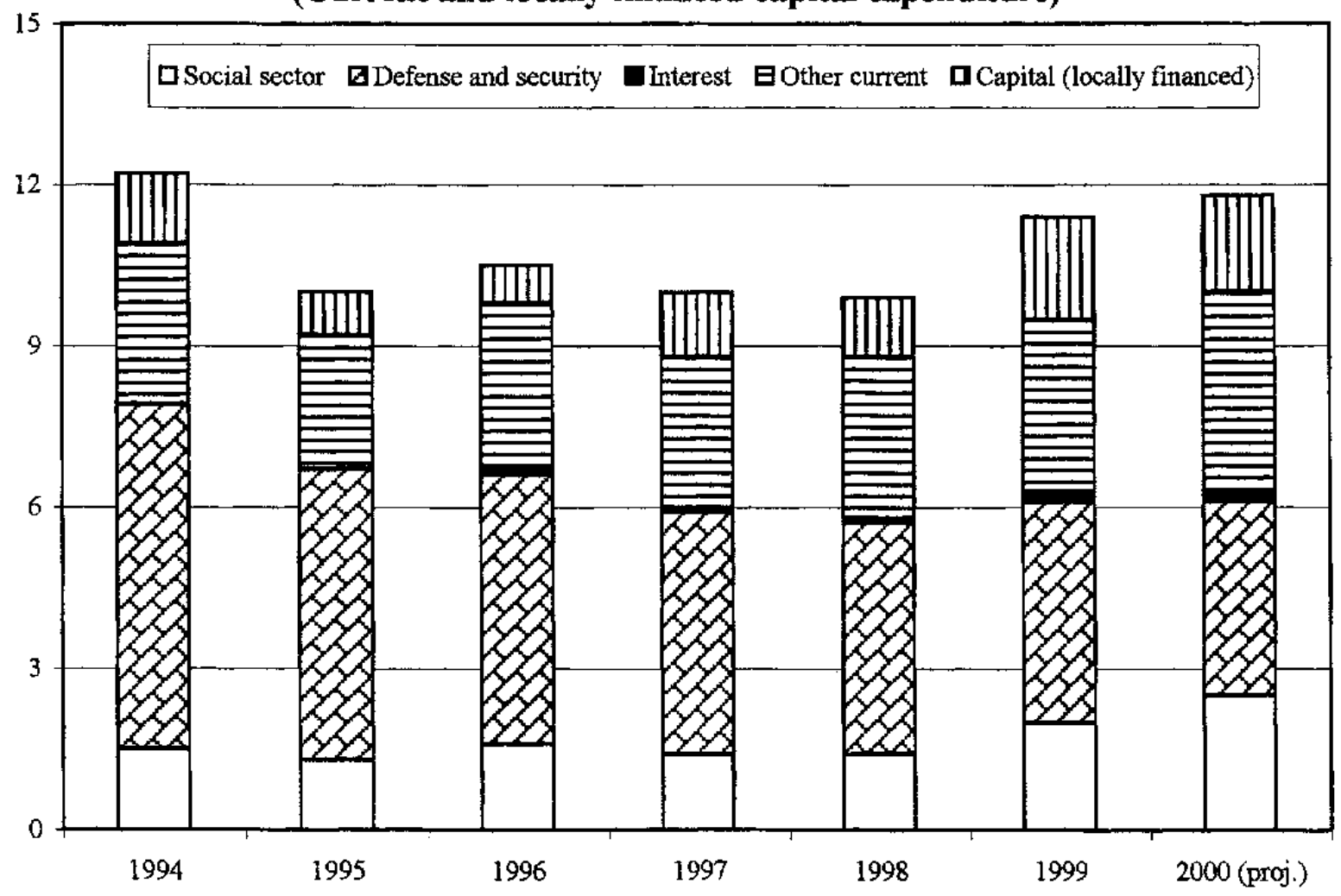

Sources: Data provided by the Cambodian authorities, and Fund staff estimates and projections. 
Chart III.3 Cambodia: Structure of Customs Duties

Composition of customs duties by goods in 1999

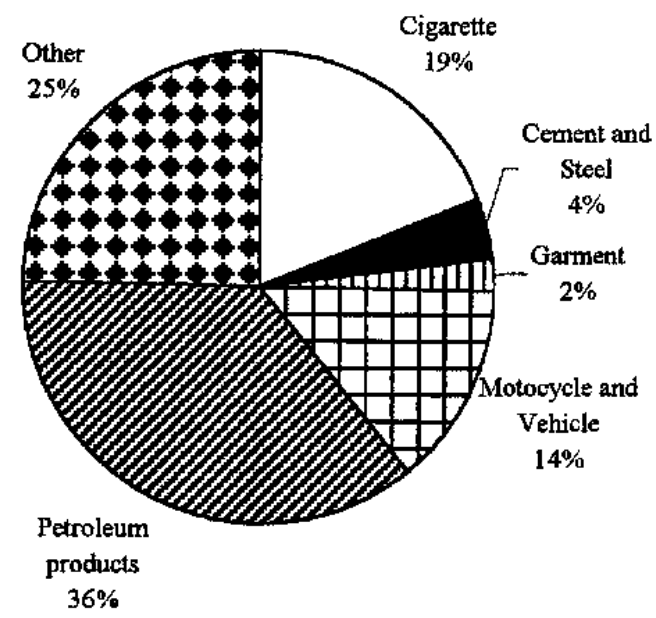

Composition of customs imports in 1999

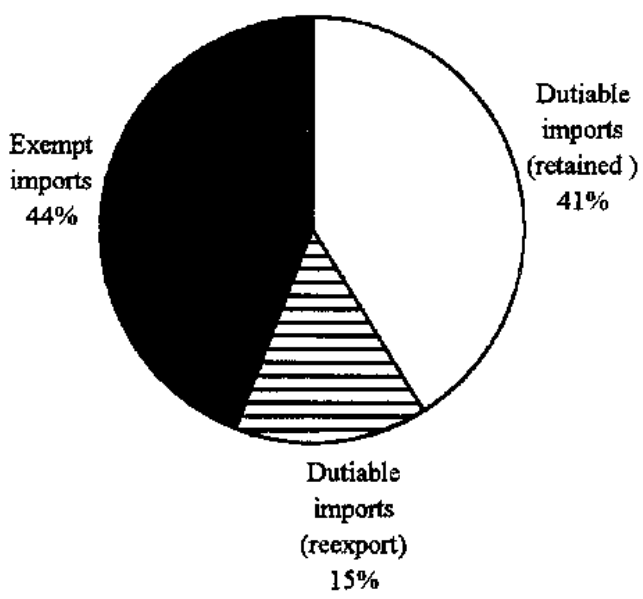

(CR billion)

Customs duties development

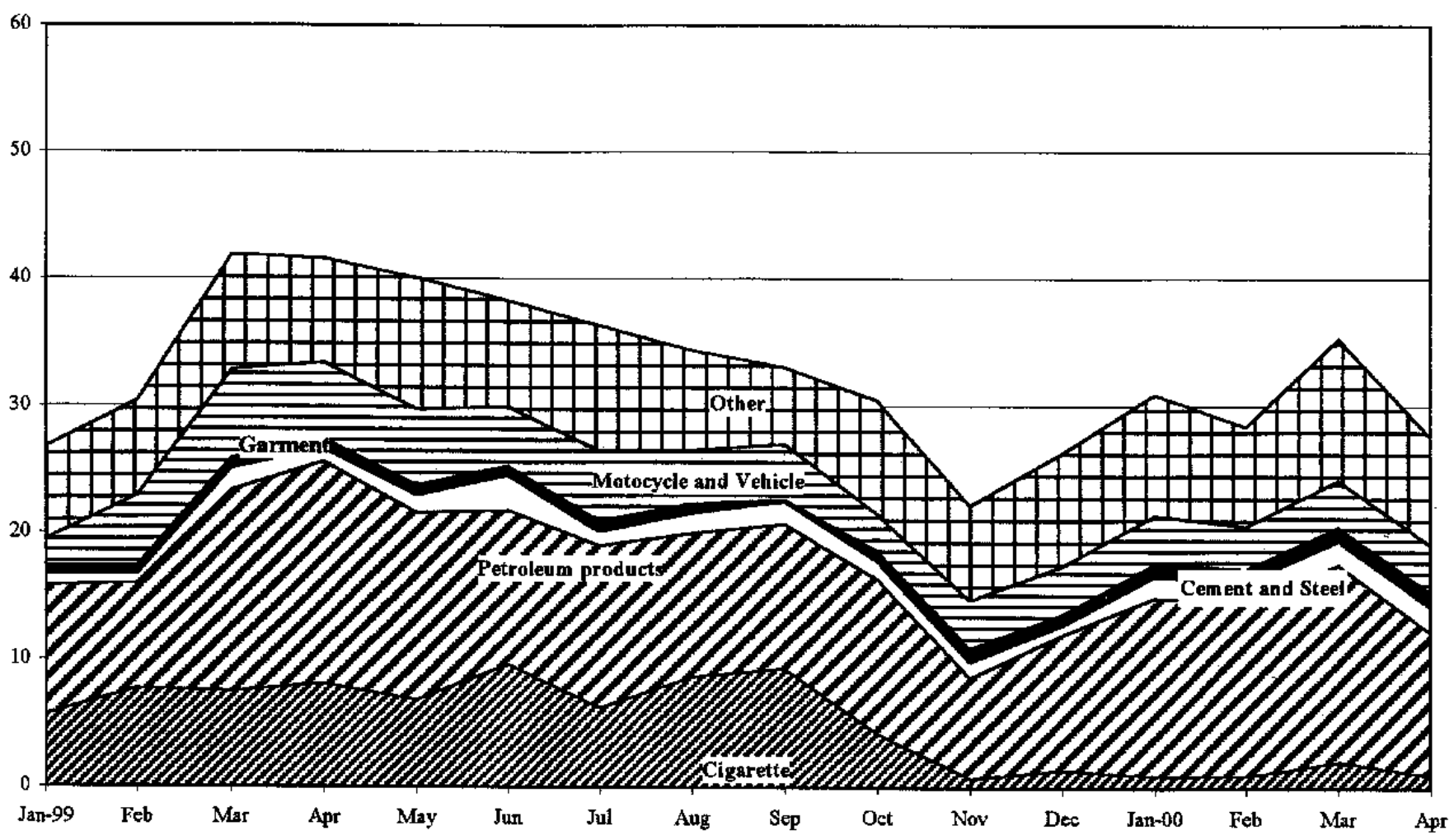

Source: Data provided by Cambodia authorities, and Fund staff estimates. 


\section{Dollarization and The Monetary Regime In Cambodia}

1. The financial system in Cambodia is characterized by very high currency and asset substitution ${ }^{1}$, mainly in U.S. dollars with Thai baht also circulating in certain regions of the country. Dollar-denominated deposits account for nearly 70 percent of measured broad money (Charts IV.1 and IV.2), and dollars in circulation are estimated to be much larger than measured broad money. This chapter first reviews the historical background and trend of dollarization in Cambodia, then outlines the costs and benefits of adopting a foreign currency as legal tender, and concludes by discussing the various policy options for Cambodia in the medium term.

\section{A. History of the Monetary System}

2. The low trust in the domestic currency and in the banking system is a legacy of devastation and civil strife during the past three decades. After gaining independence in 1953, Cambodia maintained peace and economic growth for the next 17 years until the increasing strife in the region led to internal political turmoil. The period of 1970-75 was characterized by a civil war, which finally brought the Khmer Rouge to power in April 1975. The Khmer Rouge regime launched a radical experiment in communal economic and social organization: private property was outlawed, money and banks were abolished, and even barter trade was officially banned, as workers were paid in food rations.

3. A new regime came to power in 1979, and the riel was reintroduced as the domestic currency in 1980 , although the political structure and security situation continued to be unsettled. Confidence in the domestic currency was further eroded by triple-digit inflation during 1988-92 as a result of substantial monetization of budget deficits. A parallel currency (the Khmer riel) was reportedly introduced by Khmer Rouge in the areas under their control in March 1993, although no information is available on the extent of its circulation. The high rates of inflation and continued political instability induced the public to shift from the riel to foreign currencies and gold.

4. The use of the dollar was further facilitated by large foreign exchange inflows associated with the United Nations operations and the return of expatriate Cambodians in early 1990s. The operation of the United Nations Transitional Authority in Cambodia (UNTAC)-one of the largest and most expensive UN operations ever mounted-cost $\$ 1.7$ billion during 1991-92, most of which was spent for rent and local services by the 15,500 deployed troops and 6,000 civilians. Not surprisingly, foreign currency deposits started to be an important component of the bank deposit base in 1992.

\footnotetext{
${ }^{1}$ Currency substitution occurs when foreign currency is used as a means of payment, while asset substitution occurs when foreign currency denominated assets serve as financial assets (store of value).
} 
5. Significant progress in financial stabilization had been made under the first ESAF arrangement during the period of 1994-97, leading to sharp declines in inflation and measured velocity. Economic performance, however, deteriorated after July 1997, and central bank financing of the budget was used in 1998 for the first time in 4 years. After the formation of a new coalition government in late 1998, the political environment has stabilized and macroeconomic performance has been strengthened. In 1999, GDP growth accelerated and inflation fell to low single digits.

\section{B. Extent of Dollarization}

6. Cambodia's monetary system is characterized by a high degree of currency substitution and transactions are made mostly in cash. Prices for goods and services are routinely quoted in US dollars, and most transactions in the main cities are settled in dollars. The riel is used for small cash transactions only, and is injected into circulation primarily through government payments for goods and services (including public servants' salaries). Although foreign currency cash holdings can not be effectively measured, they are estimated to be in the range of 85-95 percent of total currency in circulation. This suggests a stock of foreign currency cash holdings several times larger than measured broad money.

7. Asset substitution is also pervasive in Cambodia, with the share of domestic to total deposits remaining at less than 7 percent. A scant 2 percent of bank assets is denominated in riel, mostly in the form of non-interest bearing vault cash and reserves with the central bank. Bank intermediation in local currency is minimal at most banks, and a number of institutions do not accept riel deposits at all. The vast bulk of lending activities consists of dollardenominated short-term trade-related credits, and is small in relation to GDP. There are virtually no restrictions on current and capital account transactions.

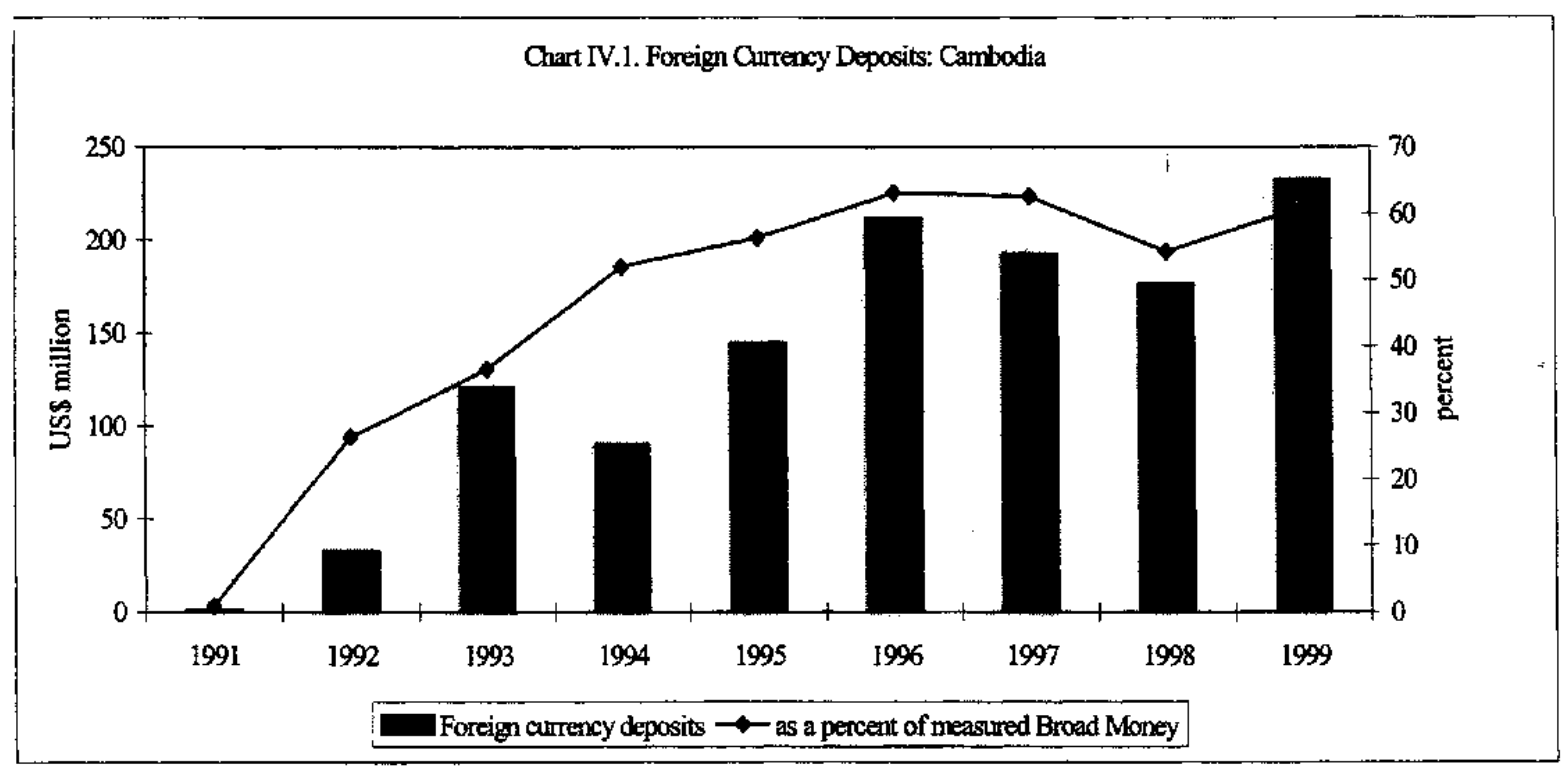




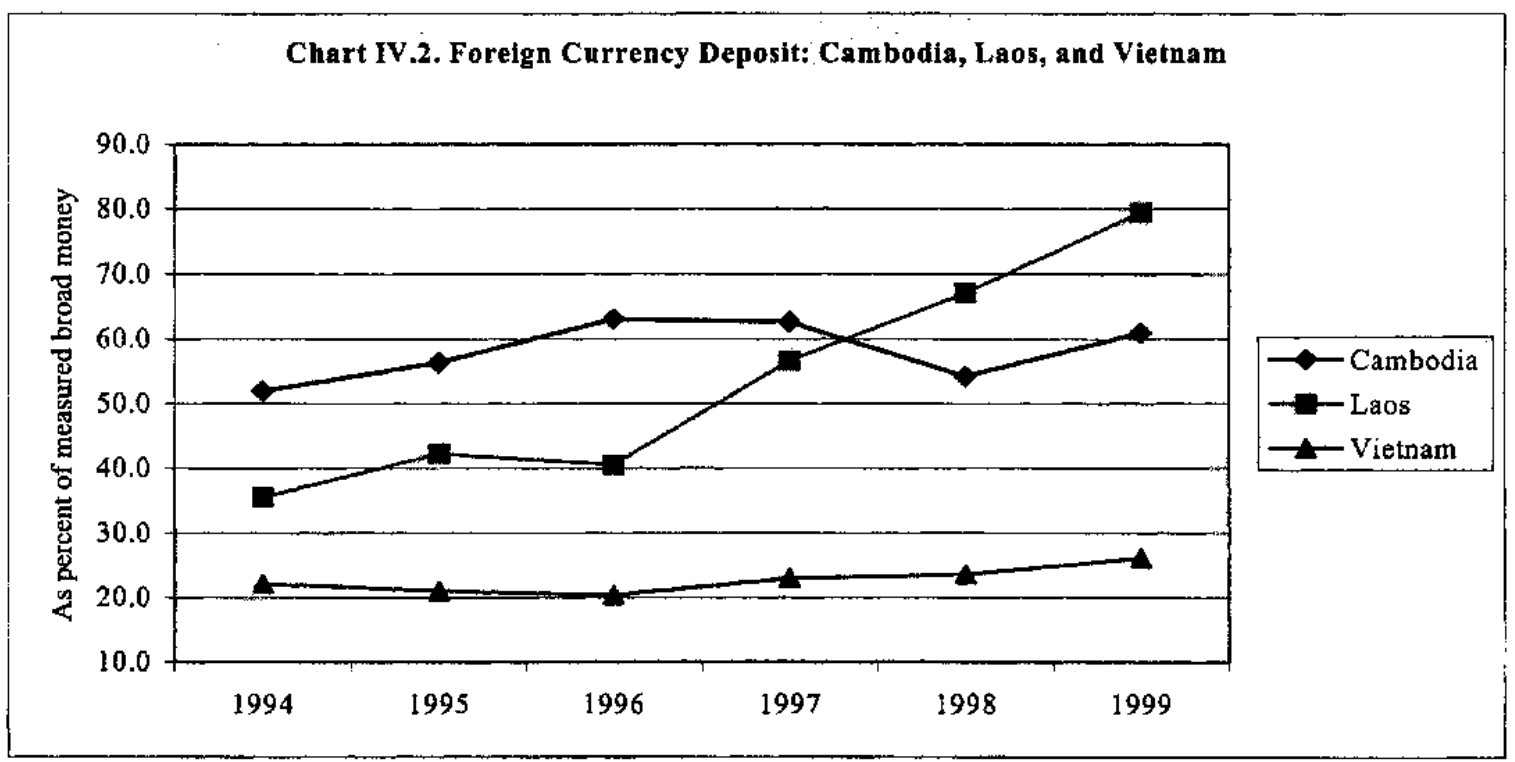

8. The use of foreign currency in Cambodia is facilitated by the existence of an active foreign exchange market, with 24 money changers licensed by the National Bank of Cambodia (NBC). This market reportedly accounts for three fourths of total foreign exchange transactions, and effectively ensures access to foreign currency. Since 1994, the $\mathrm{NBC}$ has set the official exchange rate each morning based on surveys of the rates quoted by three major dealers in the market the day before, maintaining the spread to no more than 1 percent except for periods of market turbulence. Periodically, the NBC has conducted foreign exchange auctions in which it sells to the private sector a portion of the government's foreign exchange receipts from nonproject foreign aid. The NBC has not auctioned foreign exchange since the second half of 1997 , and with economic recovery since late 1999 , has been a net purchaser of foreign exchange from the market.

9. The progress in financial stabilization since 1994 has led to significant reductions in inflation and measured velocity, but has not yet resulted in any significant reversal of dollarization, in part because of on-going political uncertainty, especially during 1997-98. Foreign currency deposits continue to be an important component of the bank deposit base, and almost fully account for changes in broad money in recent years. Increasing confidence since late 1998 has been reflected in the return of foreign currency deposits to the banking system with the share of foreign currency deposits in broad money returning to its pre-1997 level of above 60 percent.

\section{Benefits and Risks of Dollarization ${ }^{2}$}

10. Dollarization of financial systems in developing countries presents both advantages and risks. Following a period of very high inflation and unstable macroeconomic conditions,

${ }^{2}$ For a discussion of the costs and benefits of full dollarization, see "The Pros and Cons of Full Dollarization" by Berg and Borensztein, IMF Working Paper WP/00/50. 
allowing the use of foreign currency in the domestic financial systems enhances the opportunity for reintermediation and promotes financial deepening in the economy. In addition, it can lower inflation and promote more prudent macroeconomic policies, therefore lowering the risk premium for borrowing, and inducing higher investment and economic growth. It can also promote financial and trade integration with the United States, as well as reduce the frequency and scale of external crises, in particular, if the economy is exposed to large volatile capital flows. In the case of Cambodia, the destruction of economic institutions after 1970 s, economic mismanagement in the 1980 s, and the large inflow of US dollars in the early 1990 s, resulted in rapid dollarization, which at the same time has helped support the reconstruction of the economy.

11. On the negative side, full dollarization implies that the central bank completely relinquishes monetary and exchange rate policy tools, loses its lender-of-last-resort function when facing a bank run, and foregoes seigniorage revenue. In addition, in the event of a negative real shock, limitations on bank financing of the budget will constrain the use of fiscal policy to cushion the contractionary effects on the economy, and thus contribute to deflationary pressures. Even though Cambodia's high degree of dollarization has already severely limited the NBC's scope for conducting monetary and exchange rate policies, full dollarization implies a permanent elimination of an exchange rate adjustment in response to shocks. Experiences with major devaluations of rigid pegs, such as departures from the gold standard and the devaluation of the CFA franc, suggest that an "exit" option has some real value in the presence of extreme shocks.

12. The policy choice of exchange rate regime also inevitably has its political dimension. There is a question whether full dollarization by Cambodia would be compatible with deepening economic integration of ASEAN as most other partners of ASEAN maintain floating exchange rates with the US dollar. The disparity of exchange rate systems will lead to volatility in the bilateral real exchange rates of member countries, which may be problematic both on political and economic grounds. Another rarely mentioned aspect of countries' experience with full dollarization is the severe banking crisis that Panama confronted in the late 1980 s when the interbank credits lines to Panama were frozen.

13. Even under the existing high degree of dollarization, seigniorage revenue in Cambodia has been nontrivial. Seigniorage revenue represents the profits accruing to the monetary authority from its right to issue legal tender. The annual flow of seigniorage is generally defined as the increase in reserve money net of any interest payment on bank reserves, since this is the amount of resources the government can obtain without creating any future obligations to pay interest. Alternatively, as a result of issuing noninterest bearing debt (currency) and holding-interest earning assets (such as foreign currency reserves), the central bank earns a profit. These two measures, however, are equivalent in a present value sense, except for the initial stock of money.

14. Estimates of seigniorage in Cambodia using both measures are shown in Table 1. The annual increase in reserve money has been around 1-21/2 percent of GDP in the last four years, whereas central bank profits are estimated to be of the order of $0.2-0.4$ percent of 
GDP. The size of seigniorage in Cambodia in recent years does not seem to be high compared with most developing countries, although it surged in 1998 when there was a large expansion in domestic currency to finance the fiscal deficit.

Table IV.1 Cambodia: Estimates of Seigniorage

\begin{tabular}{crrrrrr}
\hline & 1994 & 1995 & 1996 & 1997 & 1998 & 1999 \\
\hline $\begin{array}{c}\text { Reserve Money Approach } \\
\text { Change in reserve money (CR bn) }\end{array}$ & 57.8 & 28.6 & 135.3 & 95.5 & 257.3 & 127.3 \\
$\quad$ (In percent of GDP) & 0.9 & 0.4 & 1.6 & 1.1 & 2.5 & 1.1 \\
$\quad$ (In percent of Govt. rev.) & 19.9 & 4.8 & 21.0 & 12.7 & 29.2 & 13.5 \\
& & & & & & \\
Central Bank Profit Approach & & & & & & \\
Interest Income (CR bn) 1/ & 11.0 & 16.5 & 19.2 & 25.2 & 32.5 & 40.4 \\
$\quad$ (In percent of GDP) & 0.2 & 0.2 & 0.2 & 0.3 & 0.3 & 0.4 \\
$\quad$ (In percent of Govt. rev.) & 3.8 & 2.8 & 3.0 & 3.4 & 3.7 & 4.3 \\
$\quad$ & & & & & & \\
Memorandum items & 17.9 & 3.5 & 9.0 & 9.1 & 12.6 & 0.0 \\
CPI Inflation (final quarter basis, \%) & & & & & & \\
Change of Reserve Money (as percent of GDP) & 1.2 & 0.7 & 1.2 & 2.1 & 3.1 & 2.0 \\
Laos & 3.1 & 1.3 & 2.0 & 1.1 & 0.8 & 4.9 \\
Vietnam & & & & &
\end{tabular}

1/. Calculated as the interest rate on U.S. T-bills multiplied by the average of the beginning- and endof-period stocks of banks' reserve money. Ignores the costs of currency production. The NBC does not pay any interest on bank required reserve holdings.

Source: IMF, International Financial statistics, and staff estimates.

15. While the central bank may earn some profits from non-remuneration of banks' required reserves in foreign currency, it can not avoid foregone seigniorage that result from foreign currency in circulation. The seigniorage cost of becoming fully dollarized would be an initial purchase cost to redeem domestic currency in circulation ${ }^{3}$ plus annual loss of foregone seigniorage due to any increases in currency demand. One easy way of estimating the potential increase of seigniorage if all dollar notes in circulation were exchanged for riels is to first estimate the ratio of U.S. dollar currency to GDP. For example, if this ratio is 40 percent in $1999,{ }^{4}$ and assuming monetary aggregates grow at an average of 15 percent a year, potential seigniorage gains could increase to 6 percent of GDP a year if only riel notes

${ }^{3}$ Cambodia's net foreign reserve stood at $\$ 349$ million at the end of 1999 , more than enough to cover the $\$ 129$ million riel in circulation.

${ }^{4}$ This ratio can be derived by assuming that foreign currency cash holdings are about 90 percent of total currency in circulation as mentioned above. 
were used in circulation. Both the national budget and the $\mathrm{NBC}$ would benefit from substitution of riel notes for U.S. dollars in circulation. Table IV.2 illustrates the benefits of de-dollarization using the central bank profit approach based on the stock of riel currency in circulation as of the end of 1999.

Table IV.2. Estimated Impact of Increase in Riel Circulation 1/

\begin{tabular}{|c|c|c|c|c|c|c|}
\hline \multicolumn{2}{|c|}{$\begin{array}{l}\text { Riel notes as } \% \text { total } \\
\text { currency in circulation }\end{array}$} & \multirow{2}{*}{$\begin{array}{l}\begin{array}{l}\text { Riel in } \\
\text { circulation }\end{array} \\
\text { (USS million) }\end{array}$} & \multicolumn{2}{|c|}{$\begin{array}{l}\text { Increase in Revenue from } \\
\text { Foreign assets }\end{array}$} & \multicolumn{2}{|c|}{$\begin{array}{l}\text { Allocation of NBC Profit to } \\
\text { (US\$ million) }\end{array}$} \\
\hline & & & (US\$ million) & $\begin{array}{r}\text { as percent of } \\
\text { GDP }\end{array}$ & $\begin{array}{r}\text { Capital and Reserves } \\
(25 \%)\end{array}$ & Budget $(75 \%)$ \\
\hline Scenario I: & $30 \%$ & 387 & 12.9 & 0.4 & 3.2 & 9.7 \\
\hline Scenario II: & $50 \%$ & 645 & 25.8 & 0.9 & 6.5 & 19.3 \\
\hline Scenario III: & $100 \%$ & 1289 & 58.0 & 2.0 & 14.5 & 43 \\
\hline
\end{tabular}

1/ Assuming riel in circulation is $10 \%$ of total currency in circulation, and a 5 percent return on foreign assets.

\section{Implications for Policy}

16. While the analysis of costs and benefits of dollarization sheds some light on which country characteristics would likely make dollarization an appropriate choice, the balance of this analysis is difficult to draw, since important considerations in the analysis are hard to quantify. There is also only limited historical experience to draw from, as most economies that have adopted a foreign currency are small and politically-dependent, with the recent case of Ecuador being a main exception. In addition, given the near irreversibility of dollarization, considerations must be given to events that may be rare but cannot be ruled out from a longterm perspective, such as extreme terms of trade shocks.

17. There are essentially two monetary and exchange rate options for Cambodia: move to full dollarization, or proceed with policies expected to promote de-dollarization. A currency board arrangement is an obvious option consistent with the government's stated policy of dedollarization while maintaining much of the benefits of stability and confidence associated with dollarization. However, any potential choice of monetary and exchange rate regime requires the maintenance of sound fiscal and monetary policies (and political stability) to be effective. At present, neither the fiscal position nor the soundness of the banking system in Cambodia would appear to be sufficiently strong to support a move to full dollarization or a currency board. Therefore, it is crucial for Cambodia to continue to strengthen its fiscal position and the banking system before making any changes in the monetary regime. In view of these circumstances, the authorities' current policy is to support non-administrative and gradual de-dollarization through continued strengthening of macroeconomic performance.

18. Experiences in other countries have shown that once dollarization has occurred, it usually takes a long time for market perceptions to change. In fact, a return of confidence in the initial stages of reform often leads to an inflow of foreign currency deposits, therefore an increased degree of dollarization, as experienced by several Latin America countries and 
Cambodia in the 1990s. This points to some form of "hysteresis", as changing the uses and practices regarding the settlement of transactions is a slow process that involves institutional changes. Therefore, direct administrative measures to reverse dollarization, such as regulatory limits on foreign currency usage, will simply drive dollars offshore, further reducing financial intermediation, and are ultimately counterproductive. On the other hand, introducing high quality riel-denominated assets and paying a premium on domestic currency denominated reserves may play a catalytic role in financial deepening in the domestic currency. In addition, increasing economic integration of the rural area may also promote the use of national currency, as the riel is more widely used in the countryside. These steps, together with the maintenance of low inflation, would be expected to lead to a gradual increase in the underlying level of seigniorage over time as confidence in the local currency is further strengthened. 


\section{References}

Balino, Tomas J. T., and Adam Bennett, and Eduardo Borensztein, 1999, "Monetary Policy in Dollarized Economies," IMF Occasional Paper 171 (Washington: International Monetary Fund).

Berg, Andrew and Eduardo Borensztein, 2000, "The Pros and Cons of Full Dollarization," IMF Working Paper WP/00/50 (Washington: International Monetary Fund).

Calvo, Guillermo, and Carlos Végh, 1996, "From Currency Substitution to Dollarization and Beyond: Analytical and Policy Issues," in Guillermo Calvo, Money, Exchange Rates, and Output (Cambridge, Massachusetts: MIT Press), pp. 153-75.

Fisher, Stanley, 1982, "Seigniorage and the Case for a National Money," Journal of Political Economy, Vol. 90, pp. 295-313.

Sahay, Ratna, and Carlos A. Végh, 1996, "Dollarization in Transition Economies: Evidence and Policy Implications," in Paul Mizen and Eric J. Pentecost, eds., The Macroeconomics of International Currencies: Theory, Policy and Evidence (Gloucestershire, U.K.: Edward Elgar), pp. 195-224.

Savastano, Miguel A., 1996, "Dollarization in Latin America: Recent Evidence and Policy Issues," in Paul Mizen and Eric J. Pentecost, eds., The Macroeconomics of International Currencies: Theory, Policy and Evidence (Gloucestershire, U.K.: Edward Elgar), pp. 225-55. 


\section{Selected Aspects of Managing Forestry Resources}

\section{A. Introduction}

1. Properly managed, the Cambodia forest is capable of providing a sustainable source of government revenue and export proceeds. After the turbulence of the 1970 s and $1980 \mathrm{~s}$, Cambodia entered the 1990s with a heritage of abundant forest resources that had largely been retained, while other countries in the region had already lost a large part of their productive forests. However, with the return of stability in the $1990 \mathrm{~s}$, logging proliferated, demand for Cambodia timber increased, and extraction rapidly reached unsustainable levels, exceeding the capacity of the government to regulate activity.

2. During 1994-98 the pace of logging activity far exceeded sustainable yield. It has been estimated that if logging activity had persisted at this level, economically viable forest resources could have been exhausted by 2003. Furthermore, the economic rent associated with this resource went largely to unsanctioned parties operating outside of the formal concession system.

3. In January 1999, the government embarked on a major effort to reform the sector and restore forestry as an economically sustainable resource capable of providing a revenue stream to the government, and meeting the needs of the local community, while maintaining environmental balance and biodiversity. Initial efforts consisted more of public announcements of intent (important in their own right) and were short on effective monitoring and enforcement. However, over the last eighteen months consistent efforts have been made on many fronts-with the support of technical assistance from the World Bank and AsDB,--including reducing the extent of illegal logging and taking initial steps to improve the concession management system. While much remains to be done, the reforms underway have the potential to establish a sustainable system.

\section{B. History of the Forest Concession System}

4. Historically, the limited forest harvesting that took place in a legal and controlled manner did so under a system of collection permits and log quotas that originated in colonial times. Early in the 1990 s, the government made the decision to introduce private industrial forest concessions as the main instrument of commercial forest management. Government development funding and technical capacity were severely limited, and forest resources had the potential to attract significant foreign private investment capital. In principle, the system was based on a clear separation between regulation and management with the government setting standards and monitoring and enforcing performance, and the concessionaire responsible for planning, administration, harvesting operations, product processing and marketing.

5. The first concession was granted in 1994, and over the next three years, 33 concession areas totaling almost 7 million hectares were established. The awarding of concessions and negotiation of their terms was done without reliable resource assessment. 
As a result, the period 1994-98 was one of significant uncontrolled and/or illegal logging activity, which substantially reduced the commercial value of many forest areas. The government failed to stop illegal felling and irregular activities of concessionaires and a wide array of others active in log extraction and marketing. Its power to do so was weakened by a combination of diffuse authority among government agencies and the various levels of government, by continuing security difficulties, and by a lack of political will.

6. It is impossible to know the true extent of all illegal logging activity at any point in time. However, it is clear that logging activity during 1994-98 far exceeded estimates of sustainable yield. Estimates made by Fund staff-taking into account available information-for the purposes of making balance of payments estimates were based on exports of logs and log equivalents amounting to as much as 2 million cubic meters per year (compared to an estimated sustainable yield of 500,000 cubic meters), and may have been even higher. The pace of logging activity was so extreme that it was estimated that the commercial value of the forests would have been eliminated by 2003 if the pace of 1996-98 had continued. Moreover, logging activity that did take place did not occur within the context of a proper system of forest management dealing further damage to the forest estate.

7. Despite this large scale abuse, Cambodia still has relatively abundant natural forests that cover, according to recent estimates, about 58 percent of the country's land area. These forests have a key role in the subsistence and livelihood of the largely nural population, can be a source of sustainable export and government revenue, and represent increasingly rare forest ecosystems. Under the government's reform program, it is clear that there has been a fundamental change in this situation during 1999 and 2000 with the scale of logging activity having been successfully lowered. Illegal logging activity outside of the concession system has been substantially reduced, while oversight and regulation of the concessions has been improving. Current estimates are that the level of logging activity declined below 300,000 cubic meters in both 1999 and 2000 giving much needed room for the forest estate to recover.

\section{The Government Reform Program}

\section{Administrative measures}

8. The 17 point declaration signed by the Prime Minister on January 25, 1999 is the fundamental starting point for forestry reform (see Box V.1). The declaration is an important statement of government policy and intent to implement fundamental reform of the system, and as such, has been the foundation of all reform efforts that have followed in the last 18 months. The challenge has been in monitoring and enforcing all of the clauses of the declaration.

9. The government has taken a number of specific steps over the last year: Eleven concessions were canceled in early 1999; there has been a reduction in illegal logging, 


\section{Box V.1. Declaration of Measures to Ensure Forestry Management And Eradication of Illegal Logging: 17-Point Order (January 22, 1999)}

- $\quad$ Purchases, sales, and transportation of illegally cut logs should be ended immediately. The Department of Forestry should monitor this.

- Only forestry authorities at all levels are responsible for forestry management. Other officials and agencies should abstain from interfering in the forestry sector.

- No "transportation permits" should be granted.

- No "collection permits" for illegally cut logs should be given. Existing permits are canceled.

- No new concessions shall be granted.

- All concession contracts shall be reviewed; those that have not been implemented, as well as those that operate in violation of the contract or Cambodian law, will be canceled.

- Concessions complying with the contract shall be encouraged to equip themselves with machinery to increase the value added of their operations and products.

- The ban on exports of logs and sawn timber will be continued.

- There will be a crack down on poaching, hunting, and transporting wild life.

- Felling of trees to transform the land into private ownership is prohibited.

- $\quad$ Reforestation will be encouraged in degraded areas.

- Local authorities, military, and policy shall cooperate with the Ministry of Agriculture, Forestry and Fishery (MAFF) to enforce the above measures. Military and police forces might be requested to intervene using all means.

- The practice of collecting unofficial fees should be entirely stopped.

- Disciplinary sanctions will be taken against any individual, unit, or agency that lends its support to illegal activities. Awards will be given to those who have cracked down on such activities.

- The Law on Forest Protection and Management should be adopted as soon as possible to provide a legal framework for forestry management and underpin the government's actions.

- The MAFF shall report regularly to the government on the implementation of this declaration.

- The Ministry of the Environment shall establish a monitoring system to follow the implementation of this declaration. 
including seizure of equipment and illegally harvested logs, and the closure of hundreds of illegal sawmills; and policy and legal initiatives have been introduced. For example, a forest crime monitoring unit was established, and a comprehensive review of the concession system has been conducted. While, several important clauses of the January 1999 declaration have been broadly adhered to, several others are not yet being consistently enforced. For example, questions are still being raised as to whether concessionaires are being held responsible for violations committed on concession land. ${ }^{1}$

\section{Forest Crime Monitoring Unit}

10. The idea of establishing a Forest Crime Monitoring Unit (FCMU) came out of the 1999 Consultative Group meeting, and the unit was formally established in October 1999. The FCMU consists of three components: (i) an office in the Department of Forestry and Wildlife (DFW) to monitor forest crimes in production forests; (ii) an office in the Ministry of Environment (MOE) to monitor forest crimes in protected areas; and (iii) an independent monitor (Global Witness) to report independently on forest crimes, as well as to monitor the performance of the above two agencies.

11. The two government agencies operate parallel information systems. They provide monthly reports to a focal point at the Council of Ministers that maintain information in a computerized case tracking system. At the same time, Global Witness continues to obtain information from its own sources while also monitoring the government's response to reported violations. Updates on the operation of the FCMU are made available to the public in the form of quarterly reports. An inception report was published in October 1999 , and the first two full quarterly reports were published in January 2000 and May 2000; the next full report is expected to be published in September 2000.

12. Since its inception, the unit has suffered several problems related to less than effective coordination between different government agencies, a lack of timely release of donor funding for the operations of the unit, and some delays in allowing the independent monitor full access to all government documents. However, the unit has made substantial progress in addressing reported cases of forest crime, and represents a fundamental change from the past. Furthermore, the government's willingness to work with an internationally reputable independent monitor, and the transparency in reporting the operations of this unit, are models for other countries in similar circumstances. Despite the initial teething problems, the government remains committed to further improving the effectiveness of the unit.

\section{Concession review}

13. Not suprisingly, given the notorious past behavior in the forestry sector, the AsDB-sponsored concession review found that none of the existing concessions operated on the basis of a sustainable forest management plan. The report makes it clear that all concession areas were so degraded that completion of their initial 25 year contracts is not

'See Global Witness, May 2000. 
possible owing to the reduced forest area. It is also clear that Cambodia's forest estate cannot sustaining the number of concessions in existence. The report clearly indicates that without substantial restructuring, continued rapid depletion of commercially productive forests would lead to the irreplaceable loss of national assets of significant economic, social, and environmental value.

14. On the basis of these findings, the report recommended that the government should: (i) require all concessionaires to prepare and submit new forest management plans within a reasonable time period (three concessions were recommended for termination because of the severely depleted nature of their concessions); (ii) require all eligible concessionaires to re-negotiate and sign a new contract; (iii) establish a dialogue with concessionaires and develop and adopt a rationale for determining royalties that is based on cost, market, logistical, and risk factors; (iv) accelerate the procession of the draft Forest Law and prepare associated procedures and administrative measures; and (v) strengthen the crime monitoring capacity of the DFW and FCMU.

15. Following the completion of the concession review, the government has taken several actions toward establishing a sustainable forest concession system. First, three concessions that were no longer commercially viable were immediately canceled. For the other concessions, no cutting permits will be issued for 2000 unless required inventory information has been provided. Moreover, even for those concessions that supply the necessary information, and apply for a cutting permit after May 2000, a reduction in their annual allowable cut of 50-70 percent will be made until they have submitted proper management plans and signed new concession contracts. For the period ahead, DFW staff will closely monitor the operations of all concessions. The government has prepared a draft standard for new forest management plans and this has been made available to the concessionaires. Field work for the preparation of new management plans is expected to be carried out beginning by October 2000 , and new management plans are expected to be supplied during the course of June-October 2001. Further concessions are expected to be canceled if they do not submit new management plans.

\section{Legal framework}

16. In February 2000, the government approved a sub-decree on concession management. Based on World Bank technical assistance, the subdecree lays the foundation for improved industry performance by establishing a competitive bidding process for future concessions, criteria for pre-qualification of bids, and fundamental requirements for concession management and planning. The application of the sub-decree to existing concessions will require re-negotiation of concession agreements.

17. The Department of Forestry and Wildlife (DFW) prepared a draft Forest Law in 1999, with technical assistance from the AsDB. The draft law is detailed and comprehensive and is intended to provide a legal framework for (i) establishing the role and power of government agencies in forestry administration and enforcement; (ii) forestland classification including the establishment of a permanent forest estate; (iii) the 
rights and obligations of all parties involved in forest exploitation; (iv) forest revenue collection; (v) private and community forestry; (vi) conservation and protection of forests and wildlife; and (vii) forestry crimes and penalties. An initial draft of this law was released for public comment in May 2000. Further consultations will be needed before a final version of the law is presented to the National Assembly.

\section{Issues in Forestry Taxation ${ }^{2}$}

\section{Background}

18. During 1995-98, it has been estimated that as much as 8 million cubic meters of forest resources were cleared from the land. Proper resource pricing and monitoring should have yielded government revenue on the order of 3-4 percent of GDP per annum (about 80 percent of total tax revenue collected during this period). However, government revenue during that time amounted to only a fraction of this amount (see table below), revealing the sharp deterioration in governance.

19. The size of the revenue loss during this period reflected inadequate institutional control and enforcement capacity that led to a volume of logging far in excess of sustainable levels, as well as a failure to collect the required royalties. Existing estimates, based on sustainable use and current international prices, indicate potential government revenue from forestry is not likely to exceed $\$ 30$ million per year (about 1 percent of GDP). While the narrow financial value of the resource can be quantified to some level of precision, there are other aspects of economic value that should also be taken into account in formulating government policy. These include: (i) the value of nontimber forest products; (ii) long-term value of ecological functions such as watershed protection and carbon storage; (iii) potential benefits from eco-tourism; and (iv) preservation value. While these are difficult by their nature to quantify, they have been identified as still having the potential to yield an economic return in Cambodia, and therefore, argue for establishing a system of sustainable forest management aiming to maintain the forest and biodiversity while producing a predictable flow of timber and non-timber products and services from the forest.

Table V.1: Revenue from Forestry 1/

\begin{tabular}{lccccccc}
\hline & 1994 & 1995 & 1996 & 1997 & 1998 & 1999 & $\begin{array}{c}2000 \\
\text { (Proj.) }\end{array}$ \\
\hline $\begin{array}{l}\text { In millions of U.S. } \\
\text { dollars }\end{array}$ & 41.9 & 29.1 & 12.6 & 13.9 & 6.5 & 12.8 & 12.6 \\
In percent of GDP & 1.7 & 0.9 & 0.4 & 0.4 & 0.2 & 0.4 & 0.4 \\
\hline
\end{tabular}

1/ Includes timber royalty, export tax on timber, and license fee from timber exports.

${ }^{2}$ Some of this information is derived from annex 7 of EBS/99/188. 


\section{Current revenue system}

20. The absence of an appropriate concession management system results in extensive tax evasion and a low rate of forest revenue collection, especially through false declarations of the measured volume of timber harvested. The current forestry revenue system in Cambodia consists of three elements set administratively, with predominant reliance on the timber royalty.

(i) Timber royalty: Official rates of timber royalty, as well as the FOB reference prices, were determined in Decision No. 100 of February 27, 1995. In 1999, the government increased the royalty rate from an average of US $\$ 14 / \mathrm{m} 3$ to US $\$ 54 / \mathrm{m} 3$ (for grade 2 category). Royalties are also set for grade 1 and grade 2 timber, but the large majority of timber harvested in Cambodia is grade 2.

(ii) Export tax and license fee: Set at 10 percent of the FOB reference prices, and 1 percent of the FOB reference prices respectively. Since log exports are currently prohibited, these taxes apply only to timber products.

(iii) Reforestation tax: Reforestation tax has been imposed on all concessionaires since 1994. The rates are set separately for each concessionaire (a range of US\$2 to US\$2.6 per cubic meter).

21. The objectives of the current forest revenue system are not clear, and the system provides neither appropriate government revenue nor effectively contributes to the management of forestry resources. There has also been a lack of transparency in setting the level of forest charges, as concessionaires have often negotiated bilaterally with the government. The adjustment in royalties in 1999 was seen by the industry as arbitrary and not consistent with current international prices. Finally, to carry on business smoothly, concessionaires have often been obliged to pay facilitation fees or other forms of unofficial taxation to local authorities, police, and the military.

\section{Reforming the revenue system}

22. It is impossible to control the volume of harvesting with a tax, given the state of Cambodia's institutional capacity. Fiscal instruments alone cannot substitute for traditional regulatory approaches or establish sustainable forest management. ${ }^{3}$

23. The government is currently reviewing the existing royalty structure, and is prepared to receive input from an industry sponsored study before making further changes to the revenue system. Any changes in the revenue system would likely need to take into account the following factors:

${ }^{3}$ See for example Leruth, Paris, and Ruzicka. 
- Any changes should be consistent with administrative capacity in Cambodia (to the extent possible) and should be implemented in the context of the restructuring of concession agreements.

- A combination of an area-based fee and royalty is one alternative with the possibility that an "area-based fee" could be assessed in the form of a minimum royalty. A minimum royalty assessed on a per hectare basis could yield significant and predictable revenue for the government. Actual logging would be monitored with royalty assessments offset until minimum royalty payments are surpassed.

- Any new royalty system should ideally be structured in way that is seen by concessionaires as being more fair and predictable (e.g. to more closely reflect international price trends).

\section{E. Conclusion}

24. Reforms already undertaken in the forestry sector are substantial and meaningful. However, despite the progress that has been made, an effective system for managing forest resources has yet to be established. This is essential for establishing the sustainable use of the forest estate and remains the principle challenge for the period ahead. A problem remaining from the past that confronts the FCMU and government officials in general is that much illegal activity is still in the hands of powerful interests that can not easily be controlled. However, with determined and consistent implementation of existing plans and commitments, by the end of 2001 remaining concessions should include only those areas that can support long-term forest production (without conflict with local communities), managed by companies with demonstrated capacity, using plans of an acceptable standard, and monitored by a strengthened DFW that is supported by a clear mandate and legal framework. 


\section{References}

Asian Development Bank, "Cambodia: Towards Sustainable Forest Management", The Third Consultative Group Meeting for Cambodia, May, 2000

Fraser Thomas, Cambodian Forest Concession Review Report, March 31, 2000

Global Witness, "Made in Vietnam-Cut in Cambodia: How the Garden Furniture Trade is Destroying Rain Forests," April 1999.

Global Witness, "The Untouchables," December 1999.

Global Witness, "Chainsaws Speak Louder Than Words," May 2000.

Government of Cambodia, "Progress Report on Forest Policy Reform Process to the Local Donor Group Meeting," March 15, 2000

Gray, John W., "Forest Revenue Systems in Developing Countries," FAO, 1983.

Leruth, Luc, Remi Paris, and Ivan Ruzicka. "The Complier Pays Principle: The Limits of Fiscal Approaches Toward Sustainable Forest Management," IMF Working Paper (WP/00/51), March 2000.

Seymour, Frances J. and Navroz E. Dubash, "The Right Conditions: The World Bank, Structural Adjustment, and Forest Policy Reform," World Resources Institute, Washington, DC, 1998.

UNDP and FAO, Forest Crime Monitoring and Reporting Unit, "Inception and Quarterly Situation Report," January 2000.

World Bank, "Management Supplement to the Forest Harvest Code of Practice." World Bank/RGC Forest Concession Management Project. December 1998.

World Bank, "Cambodia: A Vision for Forestry Sector Development," 1999. 


\section{Box V.2. Types of Forest Charges}

A forestry revenue system needs to balance the objectives of providing appropriate government revenue and effectively managing forestry resources. In particular, the level of forest charges affects the rate of harvesting and the type of species or grade of trees to be harvested.

The types of forest charges can be classified by the charge-base upon which they are levied (area, volume, etc.) and evaluated in terms of the above considerations.

\section{(i) Charges on concessions}

- License fees set to fully reflect the value of the concessions. This system is easy to administer and the risk of evasions is low, but the right value of concessions and of fees is difficult to determine.

- Annual ground rental based on the area of the concession. Compared to license fees, this system can more easily accommodate the value of concessions, and therefore, this system is expected to collect a more certain amount of revenue. If the level of the charge is based simply on the total ground area, this system can be easy to administer, and the risk of evasion is low.

- Fees based on standing timber volume and the annual allowable cut. If these fees corresponded closely to the value of the concessions, this alternative system could capture a greater share of the value of concessions. However, these patterns can be difficult to measure and can be abused through manipulation of inventory figures or allowable cut estimates. This system is also likely to negatively effect forest management, since it tends to encourage rapid cutting of timber.

(ii) Charges on timber harvested (per-tree or volume based)

- Per-tree charges based on the number of trees harvested, with the charge rates varying by species group. Administratively, this system is very simple, but if charges are constant irrespective of tree diameter, they can discourage the full utilization of trees because this system will encourage the cutting of larger trees.

- Volume-based charges levied on the measured volume of timber harvested, as is now applied in Cambodia. Various types of volume-based charges are possible, from uniform to complex charges including such variables as species, log grade, market prices. To derive satisfactory fiscal revenues, volume-based charges should reflect the stumpage value of timber harvested, while keeping the system administratively simple and practical. However, if the rate is set too low, more timber will be cut, including less valuable species, lower quality logs, and smaller diameter trees, while forest revenues will be low. On the other hand, if the uniform rate is too high, this could discourage the cutting of some species, sizes and qualities of trees. Moreover, if charges are too high, they may encourage illegal activity.

(iii) Charges on timber products, at a uniform rate per cubic meter (or ad valorem) or variable with species and grade. These charges are practical where administration of volume-based charges is difficult, and where the measurement of timber products can be relatively easy. However, these charges are regarded as second best. Since timber harvested is not taxed directly, it is difficult to fully capture stumpage value by this system. In addition, this system tends to encourage inefficient processing.

(iv) Combined charges. If charges on timber harvested and on timber products are applied together, the system can better capture the stumpage value of timber. In addition, this system can reduce the risk of under-reporting or evasions through cross-checking. 
Table V.2 Cambodia: Current Status of Forest Concessions

I. Concessions Operating in $1999^{1}$

\begin{tabular}{|c|c|c|}
\hline Company & Approved AAC in $1999\left(\mathrm{~m}^{3}\right)$ & $\begin{array}{l}\text { Reported Harvest } \\
\qquad\left(\mathrm{m}^{3}\right)\end{array}$ \\
\hline $\begin{array}{l}\text { 1. GAT International Co. Ltd. } \\
\text { Koh Kong }\end{array}$ & \multicolumn{2}{|c|}{ Koh Kong } \\
\hline Kampong Thom & 52,440 & 14,715 \\
\hline 2. Colexim Enterprise & 41,027 & 41,193 \\
\hline 3. Casotim Co. Ltd. & 18,500 & 4,845 \\
\hline \multicolumn{3}{|l|}{ 4. SL. International Ltd. } \\
\hline Kratie/Mondolkiri & 129,949 & 77,060 \\
\hline Koh Kong & 88,620 & 6,810 \\
\hline 5. Mieng Ly Heng Investment Co. Ltd. & 50,112 & 18,712 \\
\hline $\begin{array}{l}\text { 6. Long Day Machinery Industry Co. Lid. } \\
\text { 7. Pheapimex Fuchan Cambodia Co. Ltd. }\end{array}$ & 34,708 & 1,732 \\
\hline K. Thom/Kratie & 141,075 & 50,830 \\
\hline Stung Treng & 69,439 & 12,306 \\
\hline S. Treng/Ratanakiri & 0 & 0 \\
\hline 8. Lansong International Co. Ltd. & 33,204 & 4,743 \\
\hline 9. Hero Taiwan Company & 18,450 & 2,494 \\
\hline 10. Kingwood Industry Pte Ltd. & 86,453 & 20,178 \\
\hline 11. Cam. Chemdar Plywood Mfg. Co. Ltd. & 37,025 & 11,080 \\
\hline 12. Sam Rong Wood Industry Pte Ltd. & 0 & 0 \\
\hline 13. Everbright CIG Wood Co. Ltd. & 48,110 & 11,639 \\
\hline 14. Super Wood IPEP Ltd. & 30,009 & 8,802 \\
\hline 15. Timas Resources Ltd. & 0 & 0 \\
\hline \multicolumn{3}{|l|}{ 16. Silveroad Wood Products Ltd. } \\
\hline Koh Kong/Pursat & 31,250 & 0 \\
\hline Koh Kong & 0 & 0 \\
\hline 17. You Rysaco Company & 0 & 0 \\
\hline 18. TPP Cambodia Timber Product & 0 & 0 \\
\hline 19. Voot Tee Peanich Import Export & 0 & 0 \\
\hline 20. Cambodia Timber Product Pty Ltd. & 0 & 0 \\
\hline TOTAL & 965,382 & 290,871 \\
\hline
\end{tabular}

'This list excludes 11 concessions covering 3.4 million hectares that were cancelled in January 1999.

II. Concessions Permitted to Harvest in 2000 (as of July 30, 2000)

\begin{tabular}{|c|c|c|}
\hline Company & Approved AAC in $2000\left(\mathrm{~m}^{3}\right)$ & $\begin{array}{c}\text { Reported Harvest } \\
\left(\mathbf{m}^{3}\right)\end{array}$ \\
\hline 1. GAT International & 35,762 & 17,432 \\
\hline 2. Youry Saco & 29,378 & 2,778 \\
\hline 3. Colexim & 27,315 & 28,297 \\
\hline 4. Mieng Ly Heng & 27,565 & 5,610 \\
\hline 5. Pheapimex Fuchan Kratiel & 28,602 & 11,086 \\
\hline Strungtreng & 15,170 & 2,733 \\
\hline 6. Cambodia Cherndar Plywood & 36,318 & 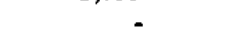 \\
\hline 7. Everbright CIG Wood & 31,459 & 8,273 \\
\hline 8. Hero Taiwan & 3,498 & - \\
\hline 9. Samrong Wood & 10,735 & - \\
\hline 10. Silveroad Wood Products Ltd. & 10,535 & - \\
\hline 11. King Wood & 13,148 & - \\
\hline TOTAL & 269,485 & 76,209 \\
\hline
\end{tabular}




\section{Chart V.1 Timber Prices.}

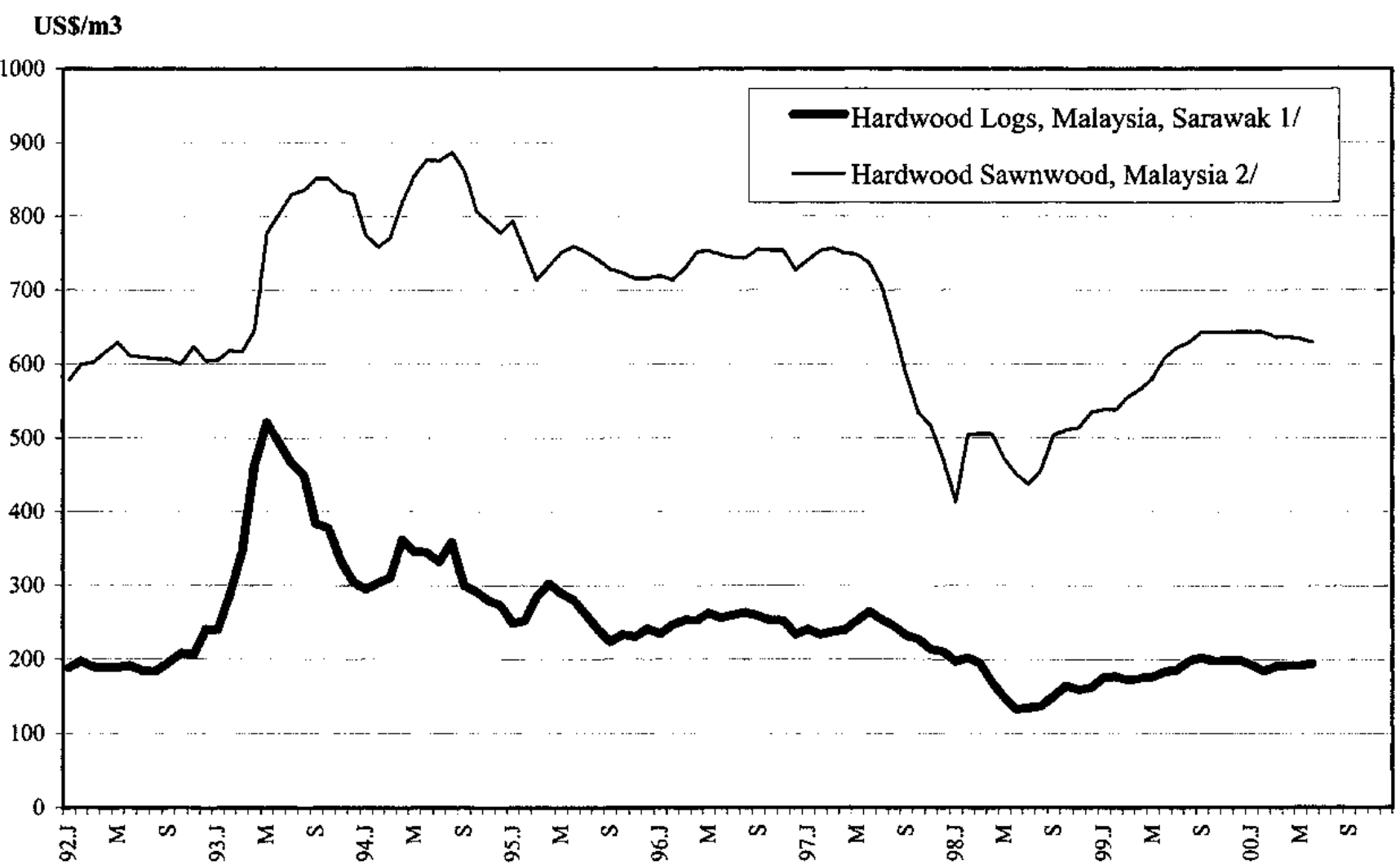

1/ Hardwood logs: Meranti, Sarawak best quality, sale price charged by importers, Japan.

2/ Hardwood sawnwood: Dark and meranti sawnwood, select and best quality, standard density, cof price at UK ports.

Source: International Financial Statistics. 


\section{Export Performance and Trade Policy}

\section{A. Introduction}

1. With the transition from a communist system in the early 1990s, Cambodia introduced a relatively open and liberal trade policy, and has recorded very high rates of export growth in recent years. A surge in garment exports in the late 1990s bas been the main driving force of this growth. Foreign investors began shifting their factories into Cambodia in 1995, and this accelerated during 1997-98. As a result, the Asian crisis in 1997 had only a limited impact on Cambodia's export performance.

2. Despite this early success, the task of export development will continue to be a challenge for the Cambodian government. First, the high growth in the 1990s partly reflects the very low stating point. Second, Cambodia still has poorly developed infrastructure, which could constrain export growth if further infrastructure investment is not made. Third, tariff reductions in the context of AFTA will underscore the importance of domestic revenue mobilization. Finally, continuing to attract foreign direct investment will be necessary to sustain export development. To make an attractive investment climate, infrastructure development will need to be complemented with a wide range of other reforms including financial sector reform, tax reform, and legal reform. This chapter reviews the recent experience in export development and discuss issues related to trade policy.

\section{B. Export Performance}

3. Cambodia's total exports grew by 29 percent per annum in the 1990 s. As political stability was restored, countries in the region generally benefited from a recovery in exports. However Cambodia's average growth rate in total exports is much higher than that of Vietnam (21 percent) or Laos ( 20 percent) (Table 1).

4. Despite the recent surge in garment exports, Cambodia's overall volume of exports remain relatively low compared to other ASEAN countries and its export potential has not been fully exploited. In line with strong export growth, various indicators of trade openness show that Cambodia has been catching up to the more dynamic economies of East Asia. The total export to GDP ratio increased from 12 percent in 1990 to 27 percent in 1999, already surpassing China (20 percent) and close to Indonesia ( 34 percent), but still much lower than Thailand (46 percent) or Malaysia (105 percent). However, per capita exports (export/population) of Cambodia was still only US\$73 in 1999, low compared to China (US\$155), Indonesia (US\$250), Thailand (US\$914), and Malaysia (US\$3,826).

5. The surge in garment exports has been the main driving force in export growth. With increased stability, and reflecting the fact that some neighboring countries were close to using all of their quota, foreign investors started to shift their production base to Cambodia. The United States extended general preferential status (GSP) to Cambodia in 1995 following a similar move by the European Union. Duty free access to those markets enabled a surge in garment exports in 1998 while other major garment exporters suffered from the impact of the 
Asian crisis. China, Hong Kong SAR, Thailand, and Indonesia, all recorded decreases in garment exports. Cambodia thus increased its market share to 1 percent for the US market and 0.5 percent for the European market. Cambodia has still not obtained access to the Japanese market (Table VI.3).

6. The potential for non-textile exports has yet to be fully exploited. Customs statistics recorded nontextile exports in the amount of US\$15-20 million per annum in the late 1990s.' In 1997, one-time exports of wood products (US\$20 million) pushed up total non-textile exports to US $\$ 50$ million. ASEAN countries used to be the main export destination before the Asian crisis, however, this went down to almost zero in 1998 (Table VI.4). Instead, other Asian countries, including Japan, emerged as an important export destination in 1998. Main export items for this region are footwear and processed wood. Europe is the second important destination for nontextile exports consisting mainly of footwear and frozen shrimp. In addition to the official statistics, a significant amount of forest products and rubber are estimated to have been exported in 1997-98; however, full details of these transactions are not available.

7. Competitiveness in terms of the real exchange rate remained broadly constant from 1994 through end-1999. However, the neighboring crisis hit ASEAN countries experienced a devaluation in their real effective exchange rates by $20-30$ percent. Thus, Cambodia's real effective exchange rate relative to those competitors has appreciated. However, the real effective exchange rate may not be a good indicator of competitiveness, since the Cambodian economy is highly dollarized and the domestic capital market is not developed. It would be desirable to construct a competitiveness indicator based on wage levels; however, given the dominance of the agricultural sector, the wage index is not available for a sufficiently long period to construct a comparable index. Given the positive aspects of the return to political stability and increased confidence, Cambodia's underlying productivity has improved, and the current level of the exchange rate is viewed as consistent with continued good performance of exports and with attracting foreign direct investment.

\section{Overview of Current Trade Policy}

8. The government has made considerable progress in establishing a modernized trade regime. During the $1960 \mathrm{~s}$, Cambodia was an exporter of agricultural products (mainly rice, rubber and corn) and the balance of payments was relatively stable. However, as the regional conflict spilled over into Cambodia in the 1970 s, foreign trade virtually collapsed. Under the trading system adopted in the eariy 1980 s, foreign trade was under a state monopoly and most transactions were governed by annual protocols with the Council for Mutual Economic Assistance (CMEA) countries (although Cambodia was not a formal member of CMEA). A process of market-oriented liberalization began in the late1980s. The state monopoly for

\footnotetext{
${ }^{1}$ Domestic exports only. A substantial amount of goods are imported and re-exported that are not fully recorded in customs statistics.
} 
foreign trade was abolished in 1987 and the foreign investment law was promulgated in 1989 , enabling private companies to engage in foreign trade. Multiple exchange rates were unified in 1990 and trade with former CMEA countries shifted to a convertible currency basis by 1991 .

\section{Export controls}

9. Cambodia has eliminated all export controls except the export ban on logs, the export quota on rice, garment quotas, and export licensing requirements for security and health reasons. There are five items that are subject to the export licensing requirements: rice, wood, garments, weapons, all vehicles and machinery for military purposes, pharmaceuticals and medical materials. The export quota on rice has been in place since 1996 as a replacement for a ban on rice exports before 1995. This quota on rice exports is not binding since the actual export volume has never reached the ceiling set by the quota, due to limited capacity to export. For 1996-97, actual rice exports were around 30,000 tons, well below the ceiling set by the quota (100,000-120,000 tons a year). A special inter-ministerial working group decides the annual ceiling for the rice export quota. Individual transactions, which should not exceed 3,000 tons, are granted an export license from the Ministry of Commerce.

10. An export ban has been imposed on specified types of unprocessed timber and sawn logs since May 1995. Buoyant economic growth recorded in the Asian countries in the early 1990 s had created a substantial increase in demand for logs. Meanwhile, the neighboring countries such as Malaysia and Thailand strengthened their control on log exports; hence, the prices of logs substantially increased. These elements, together with limited institutional capacity for proper forestry management, created a strong incentive for illegal log exports from Cambodia. The current expert ban is inefficient as it encourages excessive and costly domestic processing, and the government intends to review the log export ban in the future in line with improvements in overall forestry management.

11. An export quota has been in place for garment exports to the United States since 1999 , in response to the recent surge in garment exports from Cambodia. The authorities are implementing a flexible management to the quota allocation. Eighty percent of the quota was allocated to the individual exporters based on the previous year's exports. Ten percent of the quota was allocated as an incentive to factories for quality improvement or improvements in labor conditions, and another 10 percent of the quota was auctioned through open competitive bidding. The export quota for 1999 was based on the export results for 1998 with a 6 percent increase. The quota for 2000 was based on the 1999 results with an 11 percent increase (a 6 percent basic increase and a 5 percent additional increase, awarded as an incentive for improvements in labor conditions).

12. Cambodia currently enjoys GSP status from 26 countries, including the United States since 1995. Under GSP, Cambodia has tariff-free access to its counterparts with markets in annual quotas. The garment sector is the main beneficiary of these arrangements. 
13. The authorities place priority on the issue of improving standards since the improved standards will be important for expanding exports from agro-industries. Fulfillment of health requirements and other standards are critical for exports of agricultural products. Cambodia has already successfully exported frozen shrimp to Europe. To facilitate further growth, refrigerating facilities and other health standards need to be recognized by trading partner. countries.

\section{Import policy}

14. Quantitative restrictions on imports were all eliminated in 1994 as a part of comprehensive trade reform measures. At present, there are no quantitative restrictions on imports. The import license system was also eliminated in 1994, except for selected items such as pharmaceutical products, gold and silver, armaments and ammunitions, and various cultural and medical materials. Ministerial authorization is required for importing these items.

15. The new ASEAN-compliant tariff schedule in Cambodia, which became effective in 2000 , comprises 6,807 tariff headings and 12 rate bands, ranging from 0 percent to 120 percent. The simple average tariff rate is about 17.4 percent. Over 90 percent of the tariff headings fall under just three rate bands: 7 percent, 15 percent and 35 percent. Both import and export tariffs consist of only ad valorem duties. At present, there are no preferential tariff duties, although they are expected to be introduced in the context of AFTA. Half of the imports are tariff exempted: aid related, government imports, or investment-related imports. Tariff lines at the eight-digit level in the harmonized system totaled 3,069 as of 1999.

16. Up to now, a large proportion (over 80 percent) of exempted duties have stemmed from provisions in the investment law. The investment law grants partial or complete duty exemptions to projects in specified sectors with or without time limits. Since these exemptions are too generous given a weak tax base in Cambodia, the authorities have started to reduce the scope of these benefits. Since 1999, new investments in the garment and telecommunication sector are not eligible for tax incentives under the investment law. The second largest portion ( 10 percent) of imports with duty exemption are related to imports financed by external aid.

17. The authorities are gradually eliminating tariff concessions on imports for re-export. There is a significant transit trade with Thailand and Vietnam. Since a duty drawback system is yet to be instituted due to administrative constraints, Cambodian authorities set up a discount system on imports intended for re-export. The Ministry of Economy and Finance set certain ratios on total imports for individual items and this portion was deemed as imports for 
re-export. The re-export items cover a wide range of goods. ${ }^{2}$ In October 1999, the tariff treatment for cigarettes was unified.

\section{AFTA and WTO}

18. Cambodia was formally admitted to ASEAN in April 1999 and, as a result, has accepted the obligation to implement a number of trade liberalization measures on both the policy and administration fronts according to a specific timetable. The main mechanism for tariff reduction in the AFTA context is the Agreement on Common Effective Preferential Tariff (CEPT). All member countries are required to reduce import tariffs to levels below 5 percent within 10 years $^{3}$, and to remove non-tariff barriers such as quotas and licenses.

19. Cambodia aims at comprehensive and expedited tariff reductions in the context of AFTA. Cambodia included 47 percent of tariff lines in the list of tariff lines subject to reduction to $0-5$ percent over 10 years. This ratio is higher than other new members in ASEAN: Laos (15 percent), Vietnam ( 28 percent), and Myanmar (43 percent). The Cambodian authorities are considering expediting the timing of completing tariff reduction, since original ASEAN members will complete tariff reductions by 2003 .

20. At this time, Cambodia is in a position to implement a comprehensive and fast reduction of tariffs. Tariff revenue is concentrated on a limited number of tariff lines. Moreover, for many tariff items, domestic industries are yet to emerge, thus tariff reduction will not face domestic political objections. Lowered costs of the imported materials will be welcomed as factors for facilitating industrial development given that most domestic industries still need to rely upon imported materials and machinery.

21. Trade liberalization will be facilitated in the context of the recent application for WTO accession. Cambodia has been granted observer status in the WTO since 1995. To apply for full membership, Cambodia has already submitted its Memorandum on Foreign Trade Regime to the WTO secretariat. Future WTO accession will require general tariff reductions and customs administration reforms similar to those required in the AFTA context.

${ }^{2}$ Cigarettes ( 80 percent, Motorcycles ( 75 percent), Beer ( 50 percent), VCRs ( 85 percent), TV sets (92 percent), Audiocassettes (95 percent), gold (90 percent). In 1997, the ratio was reduced to Motorcycles ( 30 percent), Beer ( 30 percent), TV sets ( 20 percent), and Audiocassettes (20 percent).

${ }^{3}$ The Sixth ASEAN Summit held in 1998 decided to accelerate the realization of AFTA by one year, from 2003 to 2002. As a result, The six original members (Brunei Darussalam, Indonesia, Philippines, Singapore and Thailand) will reduce tariff rates to be applied to the items in the Inclusion List below 5 percent by 2002. The newer members of ASEAN will proceed according to a somewhat more gradual schedule: tariff reductions will be completed by 2006 for Vietnam and by 2008 for Laos and Myanmar. 


\section{Role of Foreign Direct Investment in Export Development}

22. Foreign Direct Investment has recently been playing a major role in export development in Cambodia. In the mid 1990s, foreign companies invested in the forestry and wood processing industries. Those companies contributed to the exports of wood products and sawn timber, although some of them are reported to have engaged in illegal log exports. The investment approval statistics indicate foreign direct investment in other manufacturing sectors (mainly wood processing) to be nearly US\$1.5 billion during the period 1994-99. However, a substantial portion of these approvals may have not been realized ${ }^{4}$.

23. There was a surge of foreign direct investment in the garment sector during 1997-98. GSP status given by the European Union and the United States, and prospects for improved political stability, were contributing factors. Foreign investments sought the comparative advantage stemming from an abundant labor force, relatively low wages, and quota free status. Given the announcement that the export quota would be based on the export results in 1998, investors competed to make record exports to secure the quota allocation for 1999. Accordingly, after the second half of 1999, there was a major slowdown of investment approvals.

24. Given the large population in the rural community, foreign direct investment created only a modest number of new jobs directly. According to the investment approval statistics, cumulative figures of potential employment by foreign investments reached 390,000 by 1998. However these figures were based on the plan incorporated in the investment application and therefore overestimate actual job creation since they include the potential employment figures for projects which eventually were not realized. For example, investment approval statistics in the garment sector indicate cumulative total potential employment is 230,000; however a recent industry survey shows about 100,000 are actually employed in the industry. Based on similar ratios, it is likely that foreign direct investment has created around $150,000-200,000$ jobs directly. Given a total labor force of six million, direct job creation through foreign direct investment still remains limited. Because of the growth of the garment industry, export generation by these foreign investments has been substantial. The productivity of the export sectors is also high compared to the rest of the economy.

\section{E. Conclusion}

25. As evidenced by the recent surge of garment exports, Cambodia has a large potential for export development that remains untapped. The government is aware of the vital importance of increasing exports as a main source of economic development in the future. Membership in AFTA is a major step in terms of trade liberalization; however, the

4 Statistics on the realization of the foreign direct investment are under compilation and not yet published. 
implementation of the tariff reductions will be delayed for several years compared to the original ASEAN six. In the next several years, the rapid pace of trade liberalization in other ASEAN countries may adversely affect the competitive position of Cambodian exports. Development of the export infrastructure, strengthening of the financial market, and enhancing the legal infrastructure, are among priority actions for export development. 


\section{References}

Fukase, Emiko and Will Martin (1999), Evaluating the Implications of Cambodia's Accession to the ASEAN Free Trade Area: A General Equilibrium Model (CGE) Approach (mimeo), (Washington DC: The World Bank)

Kato, Toshiyasu, Chan Sophal, Long Vou Piseth (1998), Regional Economic integration for Sustainable Development in Cambodia, CDRI Working Paper 5, (Phnom Penh: CDRI).

Keat Chhon, Aun Porn Moniroth (1998), Economic Development of Cambodia in the ASEAN Context, Policies and Strategies, Cambodian Institute for Cooperation and Peace, Phnom Penh.

Sharer, Robert et al., (1998), Trade liberalization in IMF-Supported Programs. World Economic and Financial Surveys (Washington DC: International Monetary Fund)

World Bank (1999), Cambodia Public Expenditure Review, Enhancing the Effectiveness of Public Expenditures (Washington DC: The World Bank) 
Table VI.1. Selected Asian Countries: Export Performance

\begin{tabular}{|c|c|c|c|c|c|}
\hline & \multicolumn{5}{|c|}{ Export Amount } \\
\hline & \multicolumn{3}{|c|}{ (US \$ million) } & \multicolumn{2}{|c|}{ (Annual growth) } \\
\hline & 1980 & 1990 & 1999 & $1980 \mathrm{~s}$ & $1990 \mathrm{~s}$ \\
\hline Thailand & 6,449 & 22,881 & 56,684 & 15.1 & 10.6 \\
\hline Malaysia & 12,963 & 28,636 & 82,901 & 9.2 & 12.5 \\
\hline Indonesia & 21,400 & 27,065 & 52,021 & 2.6 & 7.5 \\
\hline China & 18,248 & 51,519 & 194,724 & 12.2 & 15.9 \\
\hline Vietnam & 402 & 1,731 & 9,496 & 17.6 & 20.8 \\
\hline Lao People's Dem. Rep. & 9 & 79 & 408 & 27.8 & 20.1 \\
\hline \multirow[t]{4}{*}{ Cambodia } & 5 & 86 & 858 & 37.1 & 29.1 \\
\hline & \multicolumn{5}{|c|}{ Export / GDP } \\
\hline & \multicolumn{3}{|c|}{ (Ratio in percent) } & \multicolumn{2}{|c|}{ (Change: $\%$ points) } \\
\hline & 1980 & 1990 & 1999 & $80-90$ & $90-99$ \\
\hline Thailand & 19.9 & 26.7 & 45.8 & 6.8 & 19.1 \\
\hline Indonesia & 24.7 & 23.7 & 34.3 & -1.0 & 10.6 \\
\hline Malaysia & 52.9 & 65.0 & 105.1 & 12.1 & 40.1 \\
\hline China & 6.0 & 13.3 & 19.6 & 7.2 & 6.4 \\
\hline Vietnam & 1.4 & 21.6 & 34.5 & 20.2 & 12.8 \\
\hline Lao People's Dem. Rep. & 0.9 & 9.1 & 27.7 & 8.2 & 18.6 \\
\hline \multirow[t]{4}{*}{ Cambodia } & 3.9 & 11.7 & 26.8 & 7.9 & 15.0 \\
\hline & \multicolumn{5}{|c|}{ Export / Population } \\
\hline & \multicolumn{3}{|c|}{ (In US dollar) } & \multicolumn{2}{|c|}{ (Annual growth \%) } \\
\hline & 1980 & 1990 & 1999 & $80-90$ & $90-99$ \\
\hline Thailand & 139 & 406 & 914 & 11.4 & 9.4 \\
\hline Malaysia & 942 & 1603 & 3826 & 5.5 & 10.1 \\
\hline Indonesia & 145 & 151 & 250 & 0.4 & 5.8 \\
\hline China & 19 & 45 & 155 & 9.3 & 14.7 \\
\hline Vietnal & 7 & 26 & 121 & 13.4 & 18.5 \\
\hline Lao People's Dem. Rep. & 3 & 19 & 76 & 21.3 & 16.9 \\
\hline Cambodia & 1 & 10 & 73 & 29.2 & 24.5 \\
\hline
\end{tabular}

Source: International Financial Statistics 
Table VI.2. Cambodia: Export Destination

(In millions of US dollar)

\begin{tabular}{|c|c|c|c|c|c|c|}
\hline & \multicolumn{2}{|c|}{1996} & \multicolumn{2}{|c|}{1997} & \multicolumn{2}{|c|}{1998} \\
\hline & Textile & Non-textile & Textile & Non-textile & Textile & Non-textile \\
\hline Western Hemisphere & 1.9 & 0.0 & 108.1 & 0.1 & 297.9 & 0.1 \\
\hline Of which: USA & 1.6 & 0.0 & 107.1 & 0.0 & 296.2 & 0.0 \\
\hline Europe & 73.8 & 2.1 & 117.0 & 3.6 & 179.4 & 6.0 \\
\hline ASEAN & 2.0 & 9.7 & 0.2 & 7.0 & 0.2 & 0.4 \\
\hline Other Asia & 0.9 & 10.7 & 1.7 & 39.9 & 1.3 & 7.9 \\
\hline Of which: Japan & 0.2 & 0.4 & 0.5 & 1.7 & 0.7 & 4.9 \\
\hline Other areas & 0.3 & 0.3 & 0.2 & 0.2 & 0.3 & 0.0 \\
\hline Total & 78.9 & 22.7 & 227.1 & 50.8 & 479.0 & 14,4 \\
\hline
\end{tabular}

Source: Ministry of Commerce 
Table VI. 3. International Garment Trade, 1992-98

(In millions of US dollar)

\begin{tabular}{|c|c|c|c|c|c|c|c|}
\hline & 1992 & 1993 & 1994 & 1995 & 1996 & 1997 & 1998 \\
\hline Total exports & 132,300 & 128,780 & 140,410 & 157,540 & 165,430 & 181,280 & 179,640 \\
\hline \multicolumn{8}{|l|}{ Of which: } \\
\hline China & 16,704 & 18,441 & 23,731 & 24,049 & 25,034 & 31,803 & 30,048 \\
\hline Hongkong SAR & 20,060 & 20,998 & 21,404 & 21,297 & 21,976 & 23,107 & 22,164 \\
\hline Korea & 6,770 & 6,166 & 5,653 & 4,957 & 4,221 & 4,192 & 4,651 \\
\hline Thailand & 3,767 & 4,179 & 4,508 & 5,008 & 3,729 & 3,686 & 3,560 \\
\hline India & 3,164 & 2,970 & 3,701 & 4,110 & 4,217 & 4,343 & 4,343 \\
\hline Indonesia & 3,099 & 3,502 & 3,206 & 3,376 & 3,591 & 2,904 & 2,630 \\
\hline Taiwan Province of China & 4,117 & 3,727 & 3,445 & 3,251 & 3,206 & 3,410 & 3,171 \\
\hline Bangladesh & 1,183 & 1,445 & 1,556 & 1,969 & 2,218 & 2,542 & $\cdots$ \\
\hline $\begin{array}{c}\text { Cambodia 1/ } \\
\text { Of which: }\end{array}$ & $\cdots$ & $\cdots$ & $\cdots$ & $\cdots$ & 79 & 227 & 479 \\
\hline USA & $\cdots$ & $\cdots$ & $\ldots$ & $\ldots$ & 2 & 107 & 296 \\
\hline EU & $\cdots$ & $\cdots$ & $\ldots$ & $\ldots$ & 74 & 117 & 179 \\
\hline \multicolumn{8}{|l|}{ Importers } \\
\hline Unites States & 32,951 & 35,605 & 38,643 & 41,367 & 43,317 & 50,297 & 55,720 \\
\hline EU (from outside the EU) & 37,087 & 36,645 & 38,705 & 42,908 & 46,235 & 45,996 & 48,796 \\
\hline Japan & 11,191 & 12,588 & 15,265 & 18,758 & 19,672 & 16,727 & 14,723 \\
\hline
\end{tabular}

Source: WTO International Trade Statistics, Cambodian Ministry of Commerce 
Table VI.4. Cambodia: MajorTrading Partners

(In thousands of US dollar)

\begin{tabular}{llll}
\hline 1996 & 1997 & 1998 \\
\hline
\end{tabular}

\section{Textile}

$\begin{array}{lrlrlr}1 \text { United Kingdom } & 37,202 & \text { 1 U.S.A } & 107,086 & 1 \text { U.S.A } & 296,180 \\ 2 \text { Gerrnany } & 16,916 & \text { 2 United Kingdom } & 39,823 & \text { 2 Germany } & 116,728 \\ \text { 3 France } & 6,474 & \text { 3 Germany } & 30,621 & 3 \text { United Kingdom } & 26,031 \\ \text { 4 Belgium } & 4,059 & \text { 4 France } & 15,073 & 4 \text { France } & 11,610 \\ \text { 5 Netherlands } & 3,516 & \text { 5 Belgium } & 5,546 & 5 \text { The Netherlands } & 6,440 \\ \text { 6 Ireland } & 3,135 & \text { 6 Italy } & 5,454 & 6 \text { Ireland } & 5,325 \\ \text { 7 Singapore } & 2,020 & 7 \text { The Netherland } & 4,982 & 7 \text { Belgium } & 3,165 \\ \text { 8 USA } & 1,575 & \text { 8 Ireland } & 3,170 & 8 \text { Italy } & 3,102 \\ \text { 9 Austria } & 598 & 9 \text { Denmark } & 2,772 & 9 \text { Denmark } & 2,067 \\ \text { 10 Portugal } & 575 & \text { 10 Spain } & 2,265 & 10 \text { Canada } & 1,571\end{array}$

\section{Non-textile}

\begin{tabular}{lrlrlr} 
1 China & 6,451 & 1 China & 20,338 & 1 Japan & 4,897 \\
2 Vietnam & 4,408 & 2 Hong Kong & 10,306 & 2 Hong Kong & 2,292 \\
3 Taiwan & 3,318 & 3 Singapore & 5,543 & 3 Germany & 2,215 \\
4 Thailand & 3,117 & 4 Taiwan & 4,497 & 4 The Netherlands & 1,852 \\
5 Singapore & 1,958 & 5 India & 2,632 & 5 France & 700 \\
6 Denmark & 1,849 & 6 Japan & 1,714 & 6 United Kingdom & 639 \\
7 Korea & 422 & 7 Thailand & 1,284 & 7 Belgium & 262 \\
8 Japan & 372 & 8 Germany & 1,204 & 8 Russia & 262 \\
9 France & 174 & 9 Belgium & 772 & 9 Taiwan & 202 \\
10 Russia & 143 & 10 The Netherland & 644 & 10 Thailand & 173 \\
\hline
\end{tabular}

Source:Ministry of Commerce 
Chart VI. 1

\section{CAMBODIA}

CONSUMER PRICES AND EXCHANGE RATE DEVELOPMENTS, 1994-2000
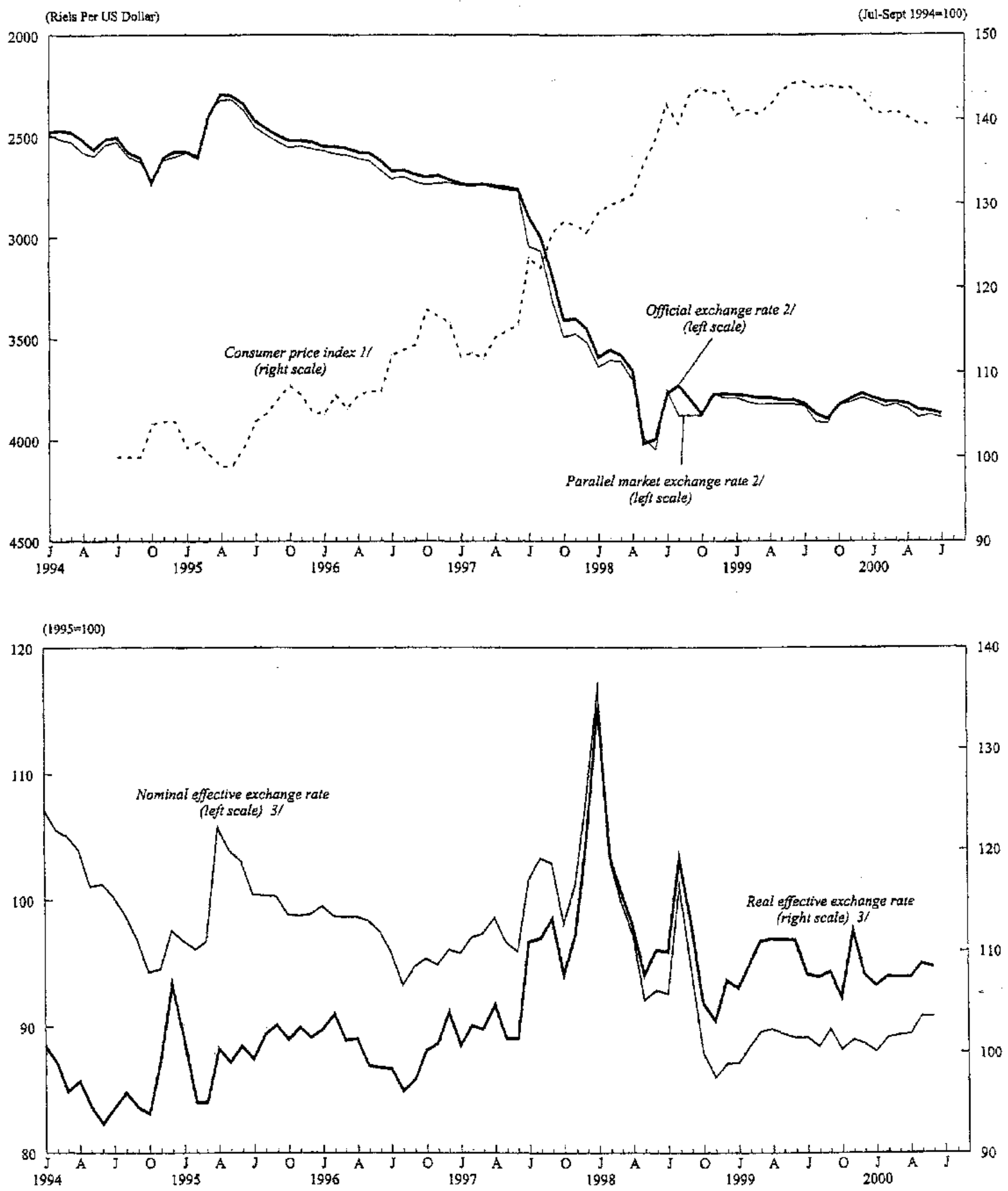

Sources: Data provided by the Cambodian authorities, and Fund staff estimates.

1/ National Bank consumer price index through December 1995; thereafter, NBC index based on change in CPI of National Institute of Statistics, which has been adopted as the official consumer price index.

2/ Riels per US Dollar, end-period buying rate.

3/ Based on the official exchange rate; an upward movement indicates appreciation of the exchange rate. 